University of Nebraska - Lincoln

DigitalCommons@University of Nebraska - Lincoln

Publications, Agencies and Staff of the U.S.

Department of Commerce

U.S. Department of Commerce

2009

Cetaceans of Southeast Alaska: Distribution and Seasonal

Occurrence

Marilyn E. Dahlheim

National Marine Mammal Laboratory, Alaska Fisheries Science Center, Seattle, WA

Janice M. Waite

Museum of Vertebrate Zoology, University of California, Berkeley

Paula A. White

National Marine Mammal Laboratory, Alaska Fisheries Science Center, Seattle, WA

Follow this and additional works at: https://digitalcommons.unl.edu/usdeptcommercepub

Part of the Environmental Sciences Commons

Dahlheim, Marilyn E.; Waite, Janice M.; and White, Paula A., "Cetaceans of Southeast Alaska: Distribution and Seasonal Occurrence" (2009). Publications, Agencies and Staff of the U.S. Department of Commerce. 157.

https://digitalcommons.unl.edu/usdeptcommercepub/157

This Article is brought to you for free and open access by the U.S. Department of Commerce at DigitalCommons@University of Nebraska - Lincoln. It has been accepted for inclusion in Publications, Agencies and Staff of the U.S. Department of Commerce by an authorized administrator of DigitalCommons@University of Nebraska - Lincoln. 


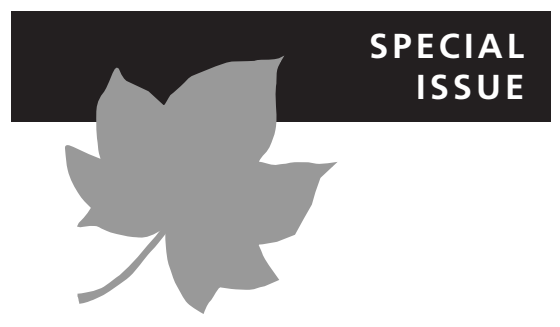

\title{
Cetaceans of Southeast Alaska: distribution and seasonal occurrence
}

\author{
Marilyn E. Dahlheim ${ }^{1 \star}$, Paula A. White ${ }^{2}$ and Janice M. Waite ${ }^{1}$
}

${ }^{1}$ National Marine Mammal Laboratory,

ABSTRACT

Alaska Fisheries Science Center, Seattle, WA

and ${ }^{2}$ Museum of Vertebrate Zoology,

University of California, Berkeley, CA, USA

Aim To assess the distribution, group size, seasonal occurrence and annual trends of cetaceans.

Location The study area included all major inland waters of Southeast Alaska.

Methods Between 1991 and 2007, cetacean surveys were conducted by observers who kept a constant watch when the vessel was underway and recorded all cetaceans encountered. For each species, we examined distributional patterns, group size, seasonal occurrence and annual trends. Analysis of variance (ANOva F) was used to test for differences in group sizes between multiple means, and Student's $t$-test was used to detect differences between pairwise means. Cetacean seasonal occurrence and annual trends were investigated using a generalized linear model framework.

Results Humpback whales (Megaptera novaeangliae) were seen throughout the region, with numbers lowest in spring and highest in the fall. Fin whale (Balaenoptera physalus) and minke whale (Balaenoptera acutorostrata) distributions were more restricted than that reported for humpback whales, and the low number of sightings precluded evaluating seasonal trends. Three killer whale (Orcinus orca) eco-types were documented with distributions occurring throughout inland waters. Seasonal patterns were not detected or could not be evaluated for resident and offshore killer whales, respectively; however, the transient eco-type was more abundant in the summer. Dall's porpoise (Phocoenoides dalli) were distributed throughout the region, with more sightings in spring and summer than in fall. Harbour porpoise (Phocoena phocoena) distribution was clumped, with concentrations occurring in the Icy Strait/Glacier Bay and Wrangell areas and with no evidence of seasonality. Pacific white-sided dolphins (Lagenorhynchus obliquidens) were observed only occasionally, with more sightings in the spring. For most species, group size varied on both an annual and seasonal basis.

Main conclusions Seven cetacean species occupy the inland waters of Southeast Alaska, with distribution, group size, seasonal occurrence and annual trends varying by species. Future studies that compare spatial and temporal patterns with other features (e.g. oceanography, prey resources) may help in identifying the key factors that support the high density and biodiversity of cetaceans found in this region. An increased understanding of the region's marine ecology is an essential step towards ensuring the long-term conservation of cetaceans in Southeast Alaska.

${ }^{*}$ Correspondence: Marilyn E. Dahlheim, National Marine Mammal Laboratory, Alaska Fisheries Science Center, 7600 Sand Point Way NE, Seattle, WA 98115, USA.

E-mail: marilyn.dahlheim@noaa.gov

\section{Keywords}

Annual trends, cetaceans, distribution, group size, multi-year investigations, seasonal occurrence, Southeast Alaska. 


\section{INTRODUCTION}

The marine ecosystem of Alaska supports some of the largest concentrations and among the highest biodiversity of marine life known to occur throughout the world. Despite the wellknown occurrence of cetaceans that reside in Southeast Alaska, relatively few peer-reviewed publications exist. Past studies have focused on single species [e.g. the harbour porpoise, Phocoena phocoena (Taylor \& Dawson, 1984), humpback whales, Megaptera novaeangliae (Baker et al., 1985, 1986, 1992; Krieger \& Wing, 1986; Straley, 1990), killer whales, Orcinus orca (Dahlheim et al., 1997)], or on broadly described cetacean occurrence within the entire study area (e.g. Scheffer, 1949, 1950; Braham \& Dahlheim, 1982; Leatherwood et al., 1982; Gaskin, 1984; Dahlheim \& Towell, 1994; Dahlheim et al., 2000). Prior to this study our basic understanding of multispecies cetacean distribution and seasonal occurrence throughout Southeast Alaska was essentially lacking.

Here we summarize our 17-year database of cetacean observations to provide an overview of multiple cetacean species distribution, group size and seasonal occurrence. Preliminary results on annual trends are also provided for some species. The scope of these data is unique in that they provide baseline information on all cetacean species inhabiting this region concurrently over a long time period. Given that various factors can influence cetacean ecology and behaviour (e.g. prey abundance, risk of predation and changes in oceanographic patterns), multi-year studies are required to document long-term patterns of distribution, group size, seasonal occurrence and annual trends.

\section{MATERIALS AND METHODS}

Between 1991 and 2007, researchers from the Alaska Fisheries Science Center's National Marine Mammal Laboratory (NMML) conducted cetacean surveys throughout the inland waters of Southeast Alaska. All major waterways from the Glacier Bay area to lower Clarence Strait (e.g. Icy Strait, Lynn Canal, Chatham Strait, Stephens Passage, Frederick Sound and Sumner Strait) were surveyed each year (Fig. 1). Many smaller

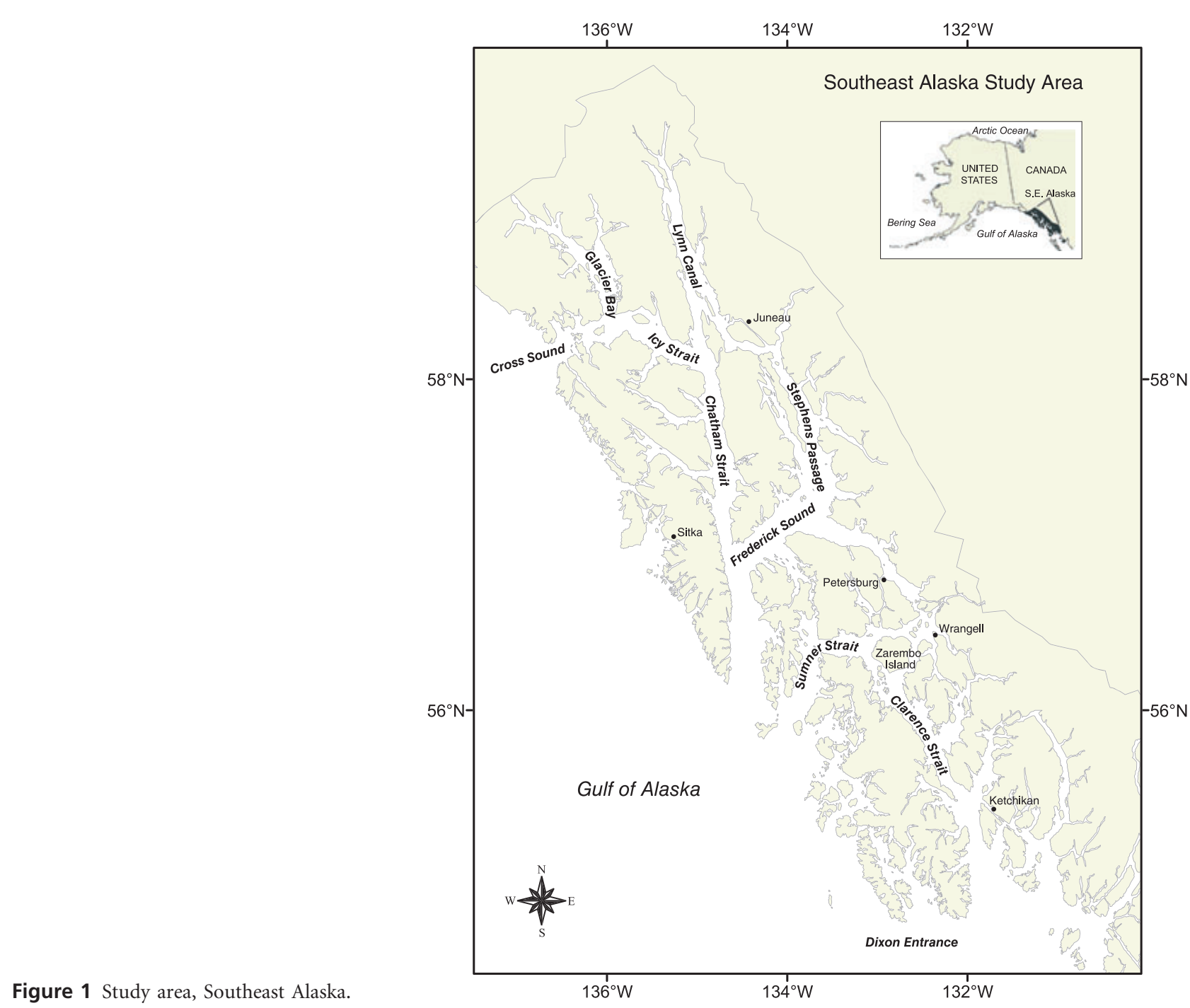

Figure 1 Study area, Southeast Alaska. 
bodies of water (bays, inlets and passages) adjacent to these major inland channels were also examined whenever time permitted. Thus, we examined a variety of habitats to include mid-channel waters, near-shore environments, protected bays and inlets, ice-laden waters and open-ocean entrances.

Surveys were carried out aboard the National Oceanic and Atmospheric Administration (NOAA) 28.36-m (93-ft) ship $R / V$ John N. Cobb, which has a bridge height of $4.27 \mathrm{~m}(14 \mathrm{ft})$. For all years, observers kept a constant watch when the vessel was underway and recorded all cetaceans encountered within the range from immediately alongside the research vessel to the shoreline (where passages were narrow), or out to the apparent horizon. During survey operations, the vessel maintained a relatively constant speed of 9-10 knots. Observers were stationed one on each side of the vessel at bridge height and used $7 \times 50$ binoculars to scan for cetaceans. For each encounter (encounter $=$ sighting of one or more animals), the following data were recorded: date, time, location, distance and angle to the sighting, species and group size. An encounter (= sighting) was defined as a socially cohesive unit travelling together in close proximity of one another with animals travelling in the same general direction. For all cruises, watches were terminated when sea conditions were greater than a Beaufort 4 or when weather conditions (e.g. fog, rain, excessive glare) interfered with sighting reliability.

Over the 17-year period, survey methodology varied depending upon the specified research objective. From 1991 to 1993, we conducted three surveys per year in spring (April/ May), summer (June/July) and fall (September/October) using line-transect methodology. The focus of this 3-year research project was to obtain abundance estimates of Southeast Alaska harbour porpoise. Line-transect surveys, conducted by a team of six observers, involved frequent use of binoculars, precise measurements of distance and angle to the sighting, and detailed accounting of weather, sea conditions and course changes (see detailed methodology as described in Barlow, 1988 and Laake et al., 1993). In 1994, our research focus changed and we began a photo-identification study of Southeast Alaska killer whales. Between 1994 and 2005, we conducted two surveys per year, one either in spring or summer and the other in fall, using four observers per cruise. Line-transect methodology was not used during these killer whale surveys; however, most sighting parameters were collected in a manner consistent with the earlier surveys so as to ensure data compatibility among years. During the killer whale surveys, distance and angle measurements to a sighting were estimated and binocular use was reduced. Although an effort log was maintained during the non-line-transect surveys, it did not include detailed information on course changes, weather or sea conditions. Thus, quantifiable effort (i.e. number of sightings per kilometre surveyed and the effect of sea/weather conditions on our ability to sight cetaceans) was only available for line-transect cruises. In the summers of 2004 and 2005, we participated in a humpback whale project that involved the collaboration of numerous researchers throughout the North Pacific. During these 2 years, our survey area was expanded to include the protected, outer coast waters of Prince of Wales Island.

In 2006 and 2007, we once again initiated studies on harbour porpoise to obtain abundance and trend information. To ensure data compatibility with our early 1990s data, linetransect surveys were completed following the exact methodology used during the 1991 through 1993 cruises. However, owing to changes in the ship's policy, our research team was limited to four observers.

Regarding killer whales, three distinct eco-types occur in Southeast Alaska (resident, transient and offshore whales; Ford et al., 1994; Dahlheim et al., 1997, 2008). The three eco-types vary in morphology, behaviour, feeding ecology and genetics (Bigg et al., 1987; Baird \& Stacey, 1988; Stevens et al., 1989; Hoelzel \& Dover, 1991; Ford et al., 1998; Hoelzel et al., 1998, 2002; Baird, 2000; Dahlheim et al., 2008). In this study, ecotype classification was first evaluated in the field by recognizing well-known individuals or pods or by observing morphological features characteristic of each eco-type. Skin samples from at least one member of each pod were obtained by biopsy darting. Laboratory analysis was later used to confirm eco-type classification by matching photographs of individual whales to existing photo-identification catalogues or through genetic analysis. Our ability to recognize killer whales both individually and by eco-type using natural markings (Ford et al., 1994; Dahlheim et al., 1997) allowed us to gather additional data on the ecology and behaviour of each eco-type. Thus, we consider each eco-type separately in this paper.

Thirty-eight cruises were completed, with nine cruises during spring (April/May; 116 days), 14 during summer (June/July; 173 days) and 15 during fall (September/October; 195 days) (Table 1). During line-transect surveys (1991, 1992, 1993, 2006, 2007), a pre-determined trackline was followed, with area coverage and effort similar among cruises. During non-line-transect surveys (1994-2005), all major channels were surveyed each cruise whereas other areas were surveyed less frequently (Glacier Bay, for example, was not surveyed during these years). An overview of seasonal effort by region for all survey data is provided in Fig. 2(a-c). For all cruises, minor changes in the ship's course were made to maximize survey coverage and reduce the detrimental effect of weather or sea conditions on our ability to sight animals.

\section{Data analysis}

For each species or eco-type observed we examined: (1) overall distributional patterns, (2) group size by year and season, and (3) seasonal and annual occurrence. When evaluating distributional patterns, we combined all sighting data by collection method (i.e. line-transect cruises conducted in 1991, 1992, 1993, 2006 and 2007 vs. the non-line-transect cruises between 1994 and 2005). Distributional maps, based upon survey method, were produced for each species.

Species' group size was examined to determine if annual or seasonal differences occurred, but, because of differences in both effort and the type of methods employed, we restricted 
Table 1 Cetacean surveys in Southeast Alaska (1991-2007).

\begin{tabular}{|c|c|c|c|c|}
\hline Year & Season & Survey dates & $\begin{array}{l}\text { Total no. days } \\
\text { surveyed }\end{array}$ & $\begin{array}{l}\text { Survey methodology } \\
\text { (no. observers) }\end{array}$ \\
\hline \multirow{3}{*}{1991} & Spring & 20 April-3 May & 14 & Line transect (6) \\
\hline & Summer & 15-25 July & 11 & Line transect (6) \\
\hline & Fall & 12-25 September & 14 & Line transect (6) \\
\hline \multirow[t]{3}{*}{1992} & Spring & 29 April-12 May & 14 & Line transect $(6)$ \\
\hline & Summer & 11-24 June & 14 & Line transect (6) \\
\hline & Fall & 10-23 September & 13 & Line transect (6) \\
\hline \multirow[t]{3}{*}{1993} & Spring & 30 April-13 May & 14 & Line transect (6) \\
\hline & Summer & 7-20 June & 14 & Line transect (6) \\
\hline & Fall & 23 September-2 October & 9 & Line transect (6) \\
\hline \multirow[t]{2}{*}{1994} & Spring & 30 April-13 May & 14 & Non-line transect (4) \\
\hline & Summer & 9-22 June & 14 & Non-line transect (4) \\
\hline \multirow[t]{2}{*}{1995} & Summer & 4-7 June & 14 & Non-line transect (4) \\
\hline & Fall & 5-18 September & 13 & Non-line transect (4) \\
\hline \multirow[t]{2}{*}{1996} & Summer & 3-16 June & 14 & Non-line transect (4) \\
\hline & Fall & 4-17 September & 14 & Non-line transect (4) \\
\hline \multirow[t]{2}{*}{1997} & Summer & 7-19 June & 13 & Non-line transect (4) \\
\hline & Fall & 2-15 September & 14 & Non-line transect (4) \\
\hline \multirow[t]{2}{*}{1998} & Summer & 4-17 June & 14 & Non-line transect (4) \\
\hline & Fall & 7-20 September & 14 & Non-line transect (4) \\
\hline \multirow[t]{2}{*}{1999} & Summer & 7-19 June & 12 & Non-line transect (4) \\
\hline & Fall & 10-23 September & 13 & Non-line transect (4) \\
\hline \multirow[t]{2}{*}{2000} & Spring & 3-16 May & 14 & Non-line transect (4) \\
\hline & Fall & 9-22 September & 14 & Non-line transect $(4)$ \\
\hline \multirow[t]{2}{*}{2001} & Spring & 3-16 May & 11 & Non-line transect $(4)$ \\
\hline & Fall & 10-24 September & 12 & Non-line transect (4) \\
\hline \multirow[t]{2}{*}{2002} & Spring & 5-18 May & 14 & Non-line transect (4) \\
\hline & Fall & 8-21 September & 14 & Non-line transect (4) \\
\hline \multirow[t]{2}{*}{2003} & Summer & 3-10 July & 8 & Non-line transect (4) \\
\hline & Fall & 12-25 September & 14 & Non-line transect (4) \\
\hline \multirow[t]{2}{*}{2004} & Summer & 1-12 July & 12 & Non-line transect (4) \\
\hline & Fall & 11-23 September & 13 & Non-line transect (4) \\
\hline \multirow[t]{2}{*}{2005} & Summer & 6-17 July & 12 & Non-line transect (4) \\
\hline & Fall & 7-20 September & 14 & Non-line transect (4) \\
\hline \multirow[t]{2}{*}{2006} & Spring & 1-11 May & 11 & Line transect (4) \\
\hline & Summer & 7-17 July & 11 & Line transect (4) \\
\hline \multirow[t]{4}{*}{2007} & Spring & 19-28 April & 10 & Line transect $(4)$ \\
\hline & Summer & 7-17 July & 10 & Line transect $(4)$ \\
\hline & Fall & 10-20 September & 10 & Line transect (4) \\
\hline & & Total $=38$ cruises & $\begin{array}{r}\text { Total survey } \\
\text { days }=484\end{array}$ & \\
\hline
\end{tabular}

seasonal group size analysis to the 5 years in which linetransect surveys were conducted. Student's $t$-test was used to detect differences between pairwise means, and analysis of variance (ANOVA $F$ ) was used to test for differences in group sizes between multiple means. Means are reported as $X \pm \mathrm{SD}$. Tests were considered significant if $P \leq 0.05$.

Cetacean seasonal occurrence and annual trends were investigated using generalized linear models (GLMs). We used the number of observed animals as the dependent variable rather than the number of observed groups (i.e. encounters/ sightings) to avoid bias that could occur if group size varied by season. The logarithm of the number of kilometres was used as an offset variable to adjust for varying survey effort, which effectively treats the dependent variable as the number of animals per kilometre surveyed. We assumed a negative binomial error model to allow for over-dispersion and we fitted a season+year model for each species, where season was a factor variable with three levels: spring, summer and fall. The analysis assumes that no seasonal or annual trend in detection probability occurred for each species. The software program used the glm.nb function in the MAss library in $R$ ( $R$ Development Core Team, 2005).

\section{RESULTS}

Seven species of cetaceans were observed: humpback whales ( $n=4046$ encounters), fin whales (Balaenoptera physalus; $n=7$ encounters), minke whales (Balaenoptera acutorostrata; 

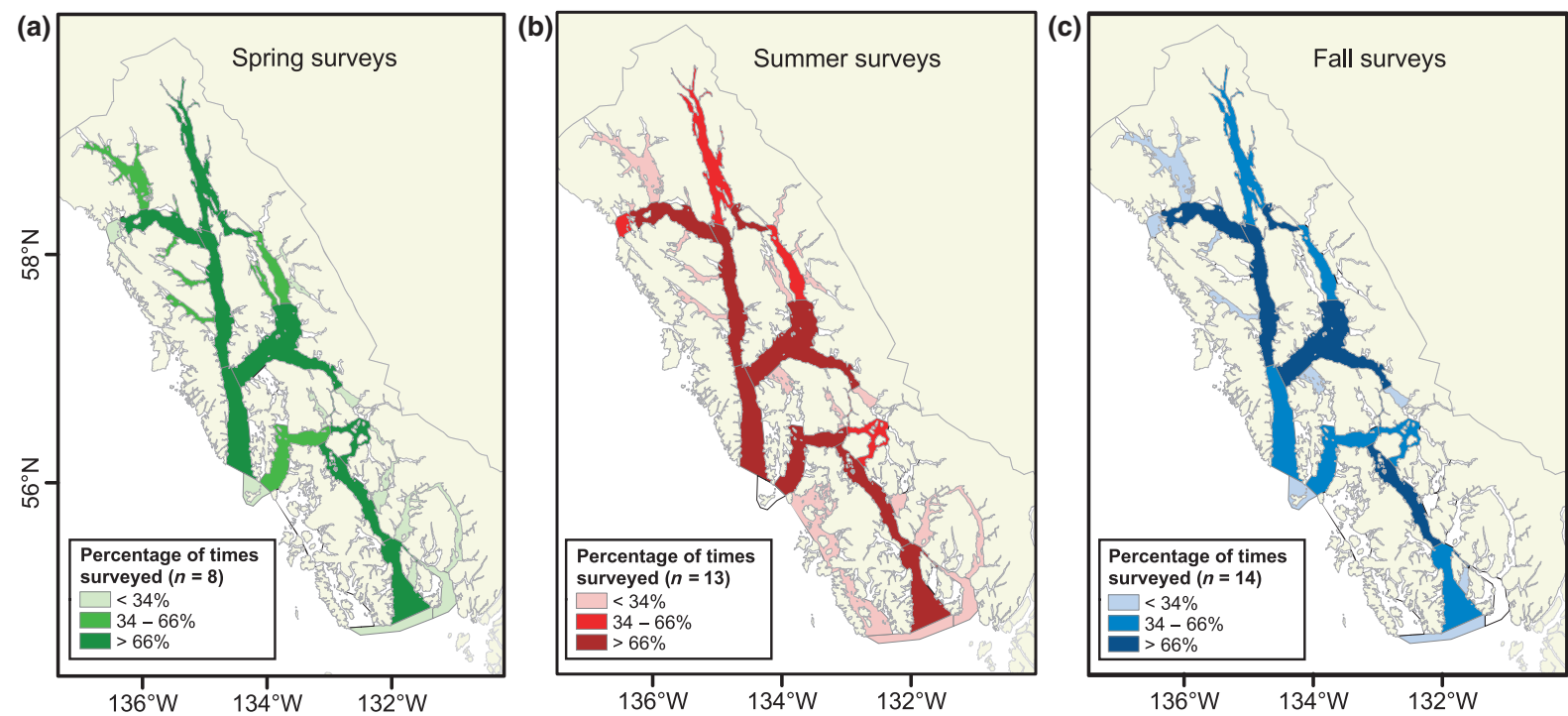

Figure 2 Survey effort by season: (a) spring, (b) summer and (c) fall in Southeast Alaska (1991-2007). Areas are grouped into three categories based on the percentage of time that the area was surveyed (i.e. $<33 \%, 34-66 \%$ and $>66 \%$ ).

$n=31$ encounters), killer whales ( $n=211$ encounters), Dall's porpoise (Phocoenoides dalli; $n=3856$ encounters), harbour porpoise ( $n=2265$ encounters) and Pacific white-sided dolphins (Lagenorhynchus obliquidens; $n=118$ encounters). Given the similarities in both methodology and effort across line-transect cruises, a seasonal distributional map was produced for each species from those years $(n=14$ cruises). We next examined the sightings of each species collected during non-line-transect cruises $(n=24)$, where effort was more variable among years and seasons. When comparing the distributional patterns for each species between the two distinct collection methods, remarkably similar patterns of distribution were found. As expected, minor differences were found based upon survey coverage of the area as explained below for each species' account.

Humpback whales were seen throughout all major waterways in the study area (Fig. 3a,b). Annual concentrations of humpback whales were seen consistently at several locations in Icy Strait, Lynn Canal, Stephens Passage, Chatham Strait and Frederick Sound. Surveys in Glacier Bay took place only during line-transect years, with humpback whales observed in all three seasons. Humpback whales in the spring appeared to congregate in particular areas (i.e. waters in and adjacent to Icy Strait, Frederick Sound and Stephens Passage). Over the course of the summer as humpback whale numbers increased, and into the fall when numbers remained high, animals were more uniformly distributed throughout the region. We found this species in a variety of habitats, including open-ocean entrances, open-strait environments, near-shore waters, areas characterized by strong tidal currents, and secluded bays and inlets. Although seen every year, humpback whales were observed less frequently in Sumner and Clarence Strait - a pattern that spanned the 17-year study. However, the number of whales observed in this southern region has appeared to increase in more recent years. During the summers of 1997,
2004 and 2005, we surveyed the protected waters of the west coast of Prince of Wales Island, where humpback whales were observed during each cruise. However, given the reduced survey effort in this region, distributional patterns should be viewed with caution.

Significant differences were found when comparing humpback whale mean group size among years (Table 2). The mean group size of humpback whales also varied significantly among seasons, being smallest in the spring $(1.38 \pm 0.70)$ and largest in the fall $(1.95 \pm 2.72)$ compared with summer $(1.65 \pm 1.36)$ (anova $F=9.12$, d.f. $=2, P=0.0001)$. Humpback whales had a distinct seasonal pattern of occurrence while occupying the waters of Southeast Alaska. Humpback whale numbers increased in the study area throughout the year, with the fewest whales seen in the spring and more whales seen during the summer and fall (Table 3). This analysis also showed a $10.6 \%$ annual increase in the humpback whale population (Table 4).

Fin whales were first observed in this study off the southern tip of Prince of Wales Island in 2004 and again in 2005 in lower Clarence Strait (Fig. 4). Fin whale observations occurred in areas exposed to the open ocean or in channels in close proximity to the open ocean. The mean group size was 2.2 and 2.0 for 2004 and 2005, respectively, and did not differ significantly between years $(t=0.149$, d.f. $=5, P>0$. 887). All encounters $(n=7)$ with fin whales occurred during summer surveys.

Minke whales were scattered throughout inland waters from Glacier Bay and Icy Strait to Clarence Strait with concentrations near the entrance of Glacier Bay (Fig. 4). All but one encounter consisted of single animals, and thus mean group size was not calculated. Although sightings of minke whales were infrequent over the 17 -year study period $(n=31)$, minke whales were encountered during all seasons, with a few animals recorded each year. 
(a)

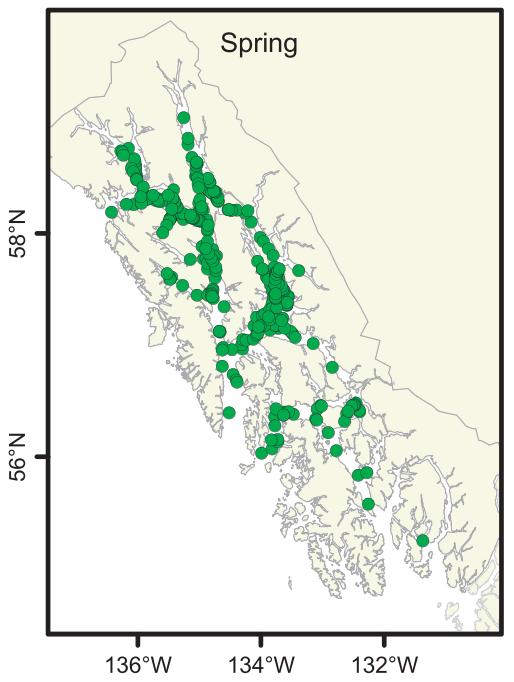

(b)

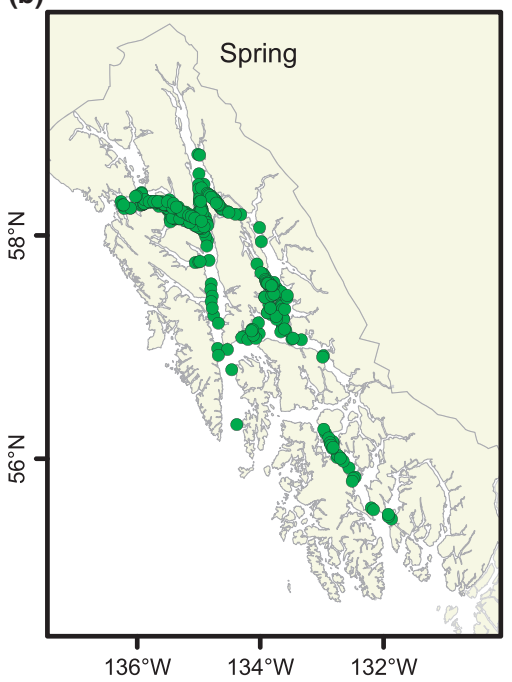

Humpback whales
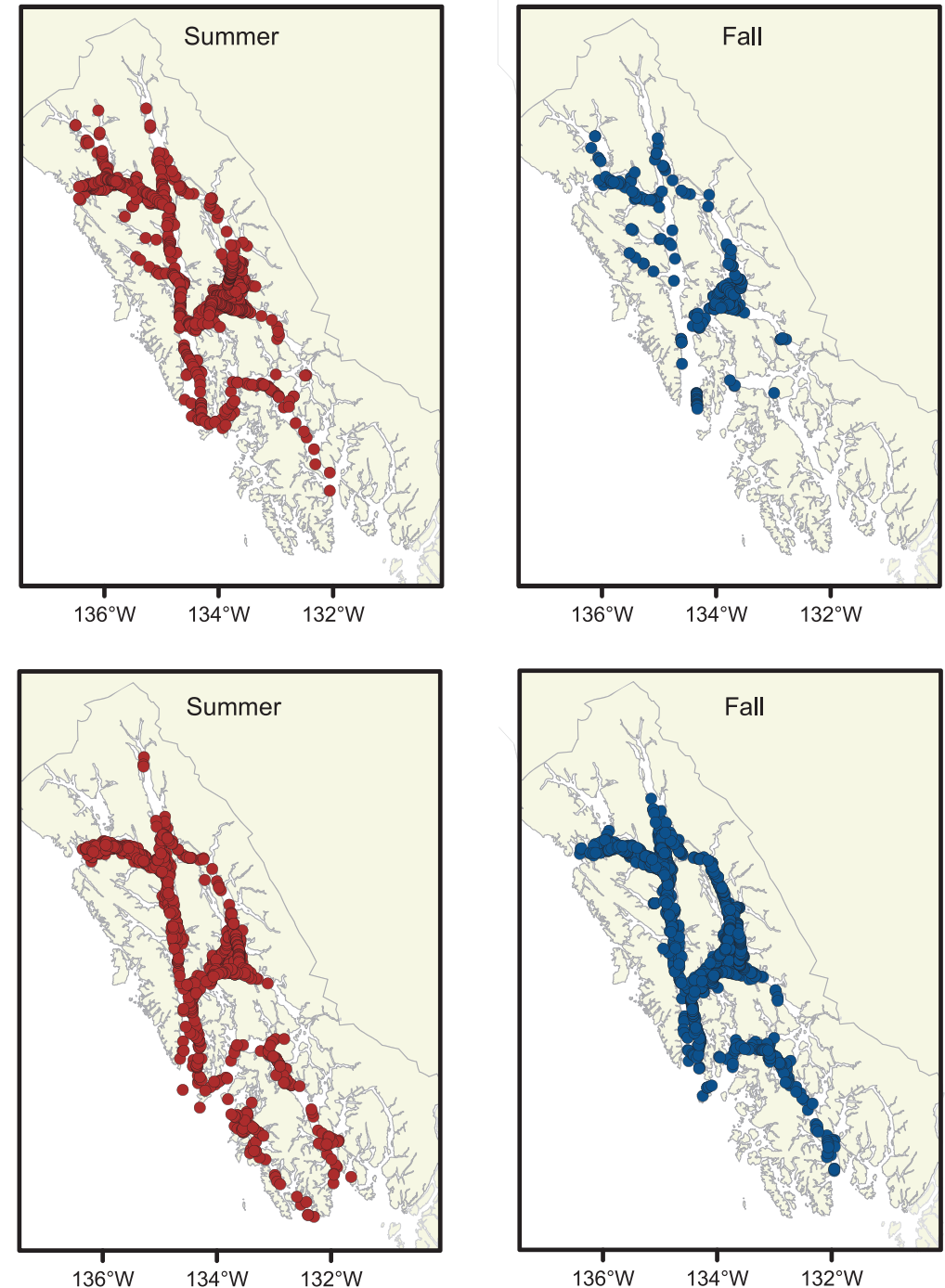

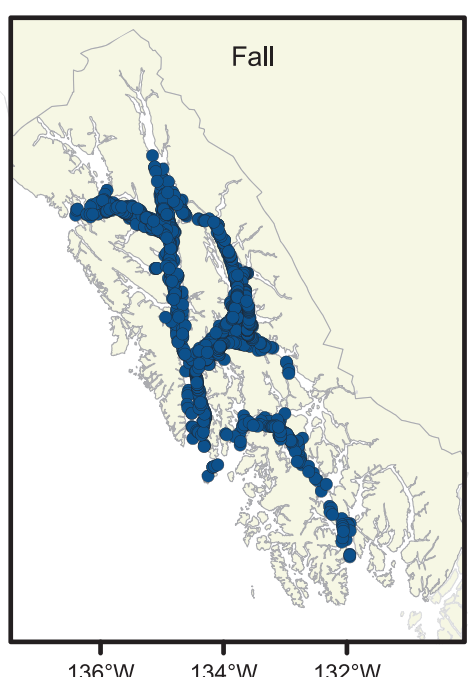

Figure 3 Seasonal distribution of humpback whales (Megaptera novaeangliae) in Southeast Alaska. (a) 1991, 1992, 1993, 2006 and 2007, representing five line-transect cruises in spring, five cruises in summer and four cruises in fall; (b) 1994-2005, representing four non-line-transect cruises in spring, nine cruises in summer and eleven cruises in fall. Each dot indicates a group sighting/encounter.

Resident killer whales were found in all major waterways as well as in protected bays and inlets (Fig. 5a,b) and were encountered during all seasons sampled (spring, summer and fall). Resident killer whales were observed in a variety of habitats, including open-strait environments, near-shore waters, bays and inlets, and ice-laden waters near tide-water glaciers. Two resident pods identified as AF and AG pods (see Dahlheim et al., 1997) were frequently encountered throughout Icy Strait, Lynn Canal, Stephens Passage, Frederick Sound and upper Chatham Strait. Other resident pods, first identified in British Columbia waters (Bigg et al., 1987), were encountered in the northern reaches of the study area (e.g. Frederick Sound) but were more frequently seen in lower Chatham Strait, Sumner Strait and Clarence Strait (A4, B, R, W, I, C pods; Dahlheim et al., 1997).

As expected, given the stable social structure reported for resident killer whales by Bigg et al. (1987), mean group size did not vary by year (Table 2). Likewise, mean group size did not vary significantly among seasons (spring: $21.54 \pm 11.8$; summer: $32.33 \pm 8.74$; fall: $19.33 \pm 16.57$ ) (ANovA $F=1.04$, d.f. $=2, P=0.36)$. In the spring of 1994 , a resident group not typically seen in Southeast Alaska (AZ pod, see Dahlheim et al., 1997) was seen in association with the two local resident groups (AG and AF pods), which increased the mean group size for that particular season (Table 2).

The seasonality of resident killer whales could not be investigated statistically owing to low encounter rates. However, a visual inspection of the number of whales seen per season (Table 3) suggested that their occurrence in the area was not different among seasons. There was, however, more variability between years in the number of animals seen during fall periods than during spring or summer.

Transient killer whales were found in all major waterways in open-strait environments, near-shore waters, protected bays 


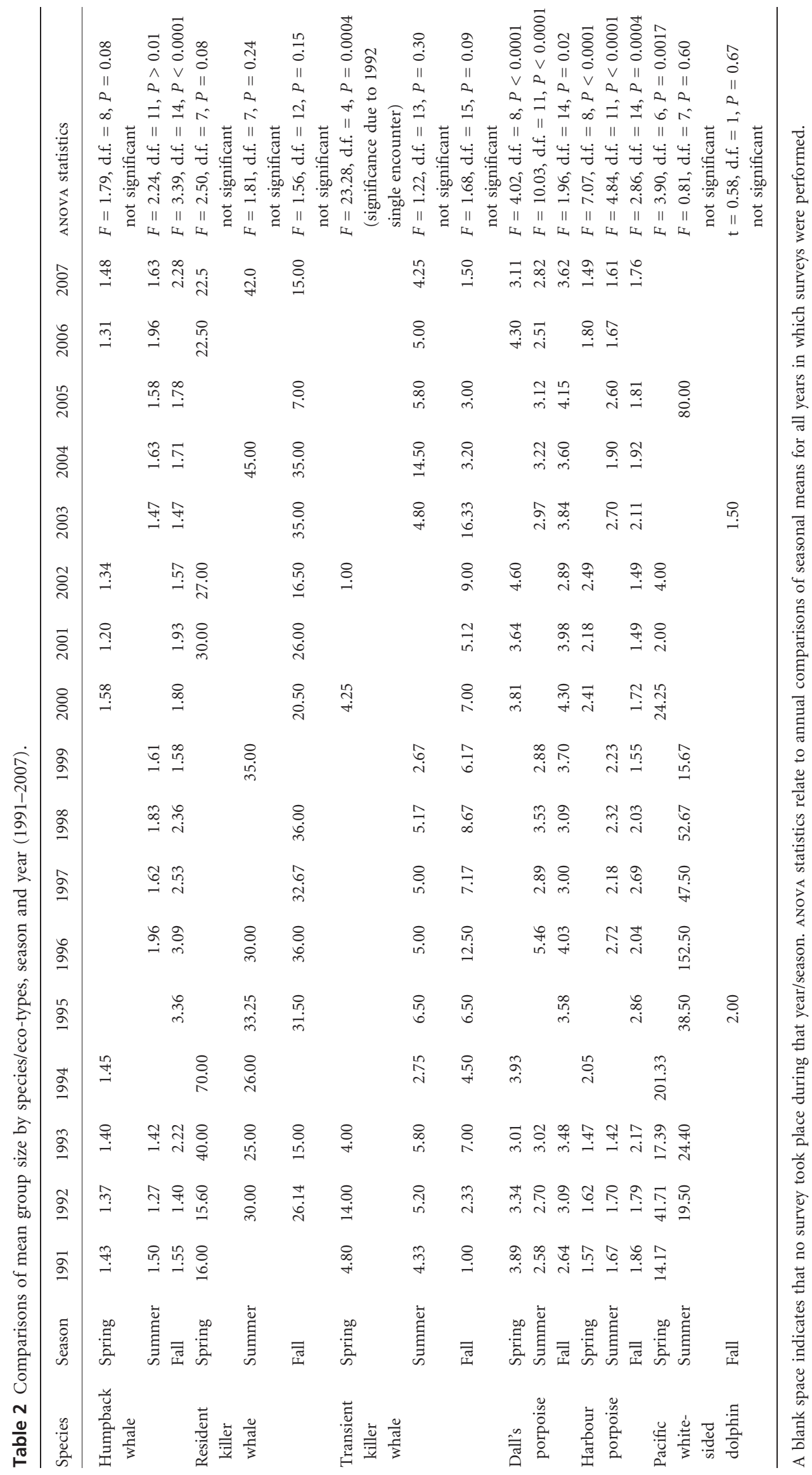


Table 3 Number of animals observed and effort data $(\mathrm{km})$ collected in Southeast Alaska during cetacean line-transect surveys aboard the NOAA R/V John N. Cobb (1991, 1992, 1993, 2006 and 2007).

\begin{tabular}{|c|c|c|c|c|c|c|c|c|c|}
\hline & Season & $\begin{array}{l}\text { Effort } \\
(\mathrm{km})\end{array}$ & $\begin{array}{l}\text { Humpback } \\
\text { whale }\end{array}$ & $\begin{array}{l}\text { Minke } \\
\text { whale }\end{array}$ & $\begin{array}{l}\text { Resident } \\
\text { killer } \\
\text { whale }\end{array}$ & $\begin{array}{l}\text { Transient } \\
\text { killer } \\
\text { whale }\end{array}$ & $\begin{array}{l}\text { Dall's } \\
\text { porpoise }\end{array}$ & $\begin{array}{l}\text { Harbour } \\
\text { porpoise }\end{array}$ & $\begin{array}{l}\text { Pacific } \\
\text { white-sided } \\
\text { dolphin }\end{array}$ \\
\hline \multirow[t]{3}{*}{1991} & Spring & 1939 & 40 & 1 & 35 & 20 & 848 & 184 & 85 \\
\hline & Summer & 1935 & 153 & 4 & & 18 & 380 & 257 & \\
\hline & Fall & 606 & 27 & & & 1 & 78 & 99 & \\
\hline \multirow[t]{3}{*}{1992} & Spring & 1960 & 58 & & 75 & 14 & 945 & 157 & 1292 \\
\hline & Summer & 1946 & 100 & & 49 & 28 & 509 & 232 & 39 \\
\hline & Fall & 1257 & 127 & 1 & 173 & 5 & 129 & 193 & \\
\hline \multirow[t]{3}{*}{1993} & Spring & 1621 & 63 & 3 & 78 & 4 & 763 & 340 & 790 \\
\hline & Summer & 1990 & 183 & 2 & & 22 & 748 & 201 & 122 \\
\hline & Fall & 1156 & 224 & 1 & 74 & 32 & 253 & 101 & \\
\hline \multirow[t]{2}{*}{2006} & Spring & 900 & 148 & 1 & 45 & & 618 & 130 & \\
\hline & Summer & 1052 & 519 & & & 23 & 282 & 129 & \\
\hline \multirow[t]{3}{*}{2007} & Spring & 789 & 86 & & 45 & & 454 & 55 & \\
\hline & Summer & 734 & 339 & & 42 & 17 & 346 & 113 & \\
\hline & Fall & 871 & 208 & & 87 & 1 & 217 & 137 & \\
\hline
\end{tabular}

A blank space indicates that no animals were seen on that survey. Owing to low encounter rates, fin whales and offshore killer whales are not shown.

Table 4 Negative binomial models of cetacean sightings by season and year collected during line-transect surveys aboard the NOAA R/V John N. Cobb (1991, 1992, 1993, 2006 and 2007).

\begin{tabular}{llrrrl}
\hline Species & Coefficients & Estimate & \multicolumn{1}{c}{ SE } & \multicolumn{1}{c}{$t$} & $P$-value \\
\hline Humpback whale & Intercept & -215.009 & 31.204 & -6.890 & $4.24 \mathrm{e}-05$ \\
& Summer & 1.070 & 0.259 & 4.119 & 0.002 \\
& Fall & 1.160 & 0.279 & 4.145 & 0.002 \\
& Year & 0.106 & 0.015 & 6.789 & $4.75 \mathrm{e}-05$ \\
Transient killer whale & Intercept & 98.740 & 85.912 & 1.149 & 0.277 \\
& Summer & 1.708 & 0.689 & 2.475 & 0.032 \\
& Fall & 0.757 & 0.749 & 1.010 & 0.336 \\
Dall's porpoise & Year & -0.052 & 0.043 & -1.215 & 0.252 \\
& Intercept & -51.948 & 19.236 & -2.701 & 0.022 \\
& Summer & -0.525 & 0.156 & -3.349 & 0.007 \\
Harbour porpoise & Fall & -1.071 & 0.171 & -6.234 & $9.7 \mathrm{e}-05$ \\
& Year & 0.026 & 0.009 & 2.667 & 0.023 \\
& Intercept & -7.109 & 26.983 & -0.263 & 0.798 \\
& Summer & 0.042 & 0.221 & 0.192 & 0.852 \\
& Fall & 0.156 & 0.237 & 0.659 & 0.525 \\
& Year & 0.002 & 0.013 & 0.185 & 0.857 \\
\hline
\end{tabular}

Owing to low encounter rates during these surveys, fin whales, minke whales, resident killer whales and Pacific white-sided dolphins are not shown. and inlets, and in ice-laden waters near tidewater glaciers (Fig. 6a,b). Transient killer whale group size did not vary significantly among years (Table 2) with the exception of 1992, when a single pod containing 14 animals was encountered. Similarly, when comparing seasons, mean group size did not vary significantly (spring: $6.0 \pm 3.70$; summer: $5.0 \pm 2.08$; fall: $3.9 \pm 2.96$ ) (anova $F=1.04$, d.f. $=2, P=0.36$ ). Transient killer whale numbers were highest in summer, with lower numbers observed in spring and fall (Table 3). Our analyses also showed an annual decrease of $5.2 \%$ for the transient killer whale population (Table 4 ).
Offshore killer whales were sighted only four times during our study. All sightings were located in the open-strait environments of Sumner or Clarence Strait (Fig. 5a,b). Encounters occurred during summer (1993, 2003) and fall (2004, 2005) surveys. The mean group size was $30.75 \pm 17.5$. Owing to the low number of encounters, the seasonality of occurrence of offshore killer whales could not be assessed.

Dall's porpoise were encountered throughout the study area, with concentrations of animals consistently found in Icy Strait, Lynn Canal, Stephens Passage, upper Chatham Strait, Frederick Sound and Clarence Strait (Fig. 7a,b). Dall's porpoise were 


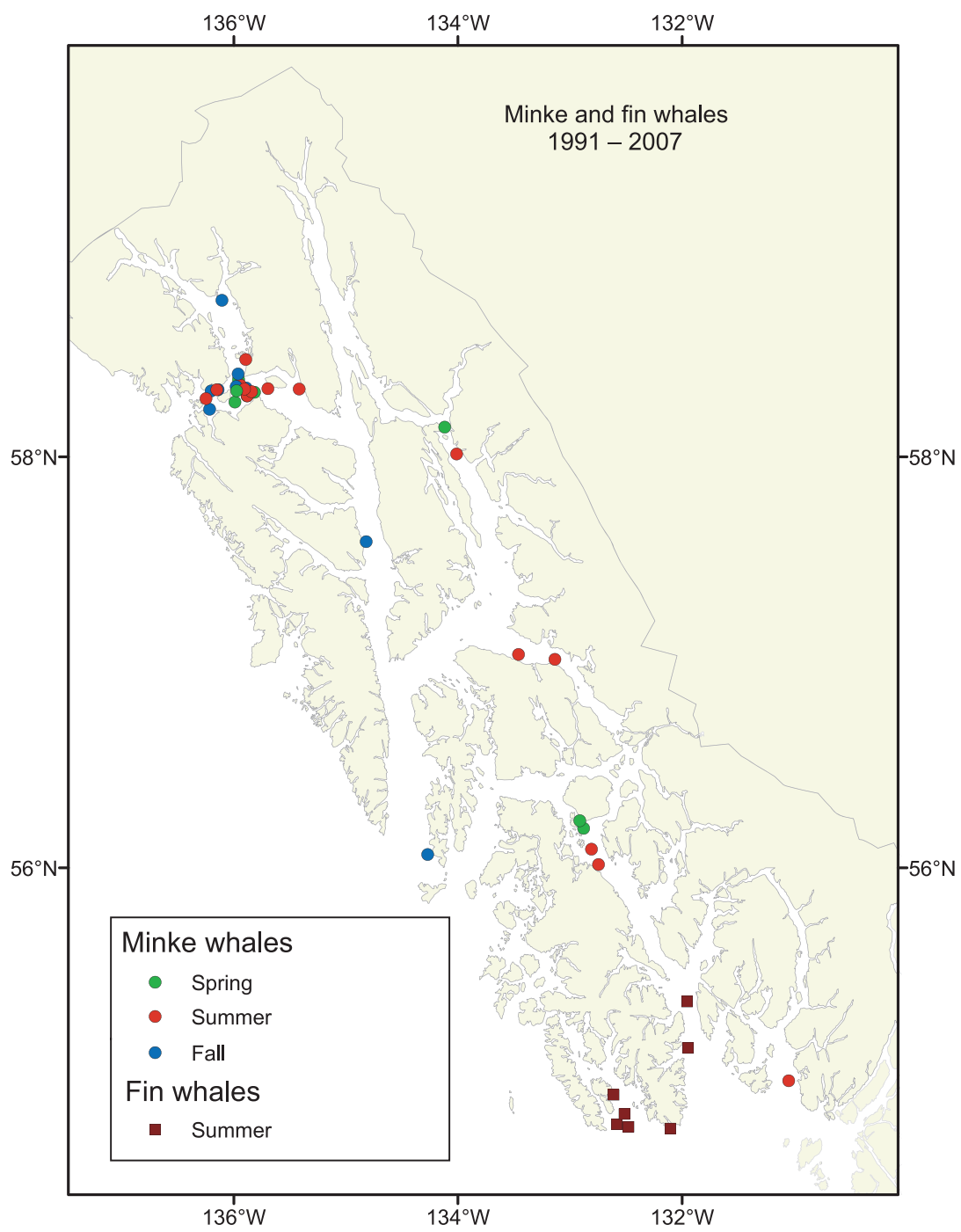

Figure 4 Seasonal distribution of fin whales (Balaenoptera physalus) and minke whales (Balaenoptera acutorostrata) in Southeast Alaska (1991-2007). Each dot indicates a group sighting/encounter. seen both in near-shore waters and in open, mid-channel areas. This species was noticeably absent from Glacier Bay and was also rare in Sumner Strait and the waters adjacent to Wrangell.

Dall's porpoise mean group size differed significantly among years (Table 2). The mean group size was significantly smaller in summer $(2.77 \pm 1.94)$ than in either spring $(3.55 \pm 3.88)$ or fall $(3.32 \pm 2.08)$ (anova $F=15.07$, d.f. $=2, P=0.0001)$. Dall's porpoise had strong seasonal patterns, with the highest numbers observed in the spring and numbers lowest in the fall (Table 3). Dall's porpoise populations increased annually by 2.5\% (Table 4).

Harbour porpoise were seen throughout the inland waters, although the overall distribution of this species appeared to be more limited than that observed for other cetaceans (Fig. 8a,b). Concentrations of harbour porpoise were consistently found in varying habitats surrounding Zarembo Island and Wrangell, and throughout the Glacier Bay and the Icy Strait regions. These concentrations persisted throughout the three seasons sampled, although during summer, and to a lesser extent during fall, harbour porpoise occupying the waters near
Wrangell appeared to expand their movements west into Sumner Strait.

Harbour porpoise mean group size varied by year (Table 2). The mean group size also varied by season, with significantly larger groups observed in the fall $(1.88 \pm 1.12)$ than in either spring $(1.56 \pm 0.86)$ or summer $(1.61 \pm 0.99)$ (ANOvA $F=11.32$; d.f. $=2, P<0.0001)$. Despite larger fall group size, there was no evidence of seasonality for harbour porpoise (Table 3 ), and only a slight annual increase $(0.2 \%)$ was found for harbour porpoise populations (Table 4).

Pacific white-sided dolphins were observed in Sumner and Clarence Straits (Fig. 9a,b) and were typically found in openstrait environments or in close proximity to the open ocean. This species was also documented in Frederick Sound, although its occurrence in that area was restricted to the early 1990s.

Significant differences were detected in Pacific white-sided dolphin mean group size among years, with a peak in mean group size in 1994 (Table 2). The mean group size was not significantly different between spring $(26.24 \pm 75.00)$ and summer $(23.00 \pm 18.85) \quad$ (Student's $t=0.11, \quad$ d.f. $=88$, 
(a)

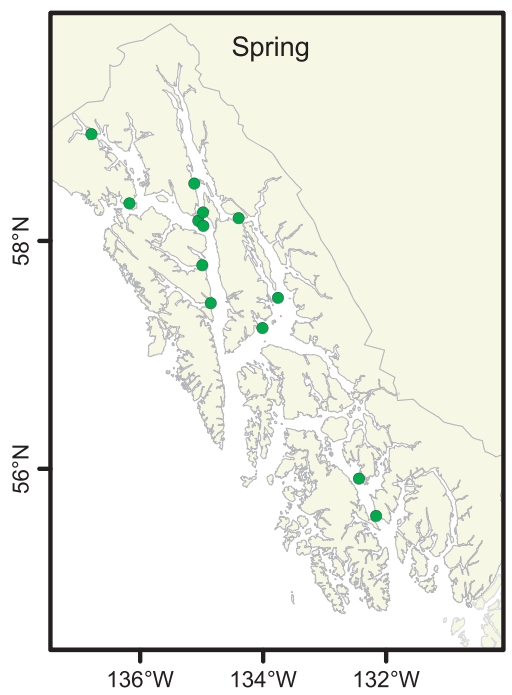

(b)

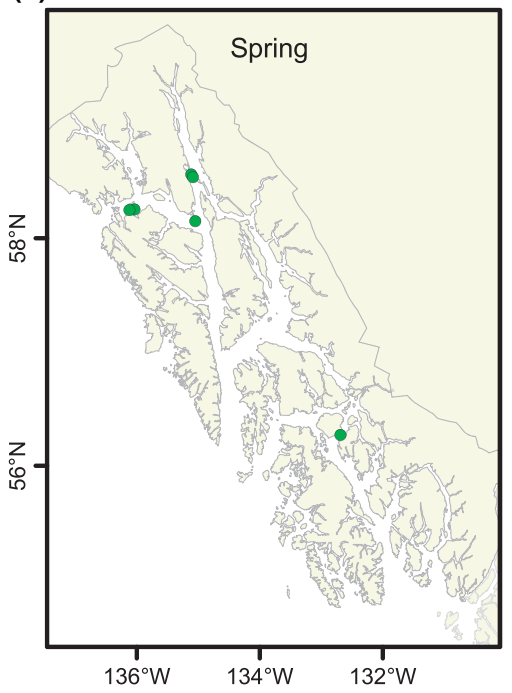

Resident and offshore killer whales
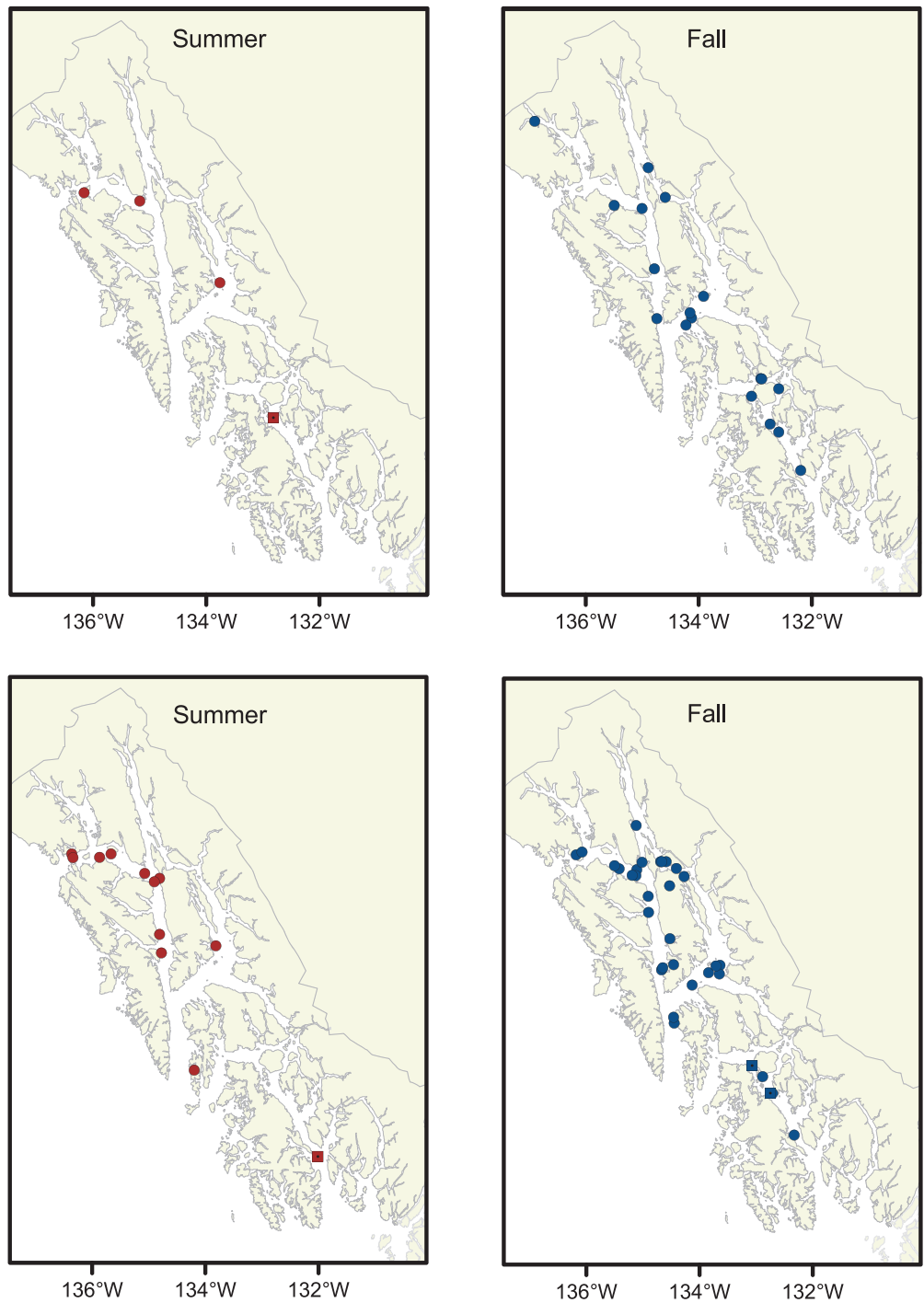

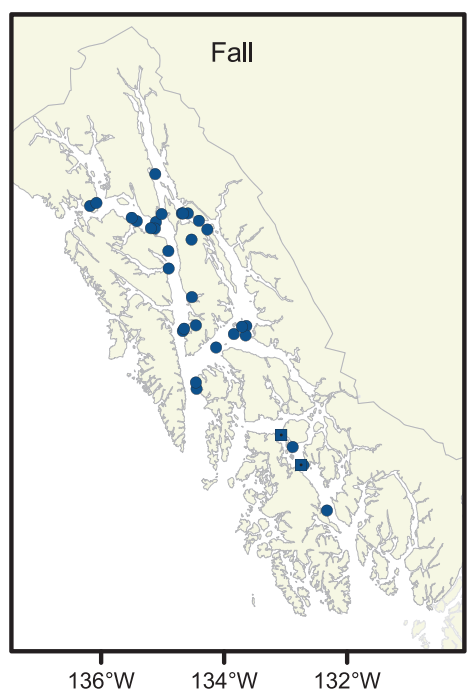

Figure 5 Seasonal distribution of resident (dot) and offshore (square) killer whales (Orcinus orca) in Southeast Alaska. (a) 1991, 1992, 1993, 2006 and 2007, representing five line-transect cruises in spring, five cruises in summer and four cruises in fall; (b) 1994-2005, representing four non-line-transect cruises in spring, nine cruises in summer and eleven cruises in fall. Each symbol indicates a group sighting/encounter.

$P=0.91)$. Owing to the low number of encounters, seasonality could not be statistically investigated. However, a visual inspection of Table 3 suggests that, when Pacific white-sided dolphins are present in Southeast Alaska, there is a strong, spring seasonal component to their occurrence.

\section{DISCUSSION}

Seven cetacean species were found throughout the inland waterways of Southeast Alaska. Humpback whales, killer whales and Dall's porpoise were widely distributed throughout the region, whereas fin whales, minke whales, harbour porpoise and Pacific white-sided dolphin distributions were more restricted (Figs 3-9). Despite extensive surveys throughout inland waters, fin whales were seen only in the southern portion of our study area (i.e. lower Clarence Strait, southwestern tip of Prince of Wales Island); that is, in areas close to open-ocean waters. In the case of minke whales, most sightings occurred near the entrance of Glacier Bay, and therefore animals in this area may represent a small, localized population - an observation consistent with studies of minke whales in other areas (Dorsey, 1983; Dorsey et al., 1990). Similarly, harbour porpoise were found consistently in the same areas throughout the 17-year study period, suggesting that this species may also occur as local residents. Based on mtDNA analysis, Chivers et al. (2002) found that harbour porpoise in California, Oregon and Washington were organized into relatively small demographically isolated subunits. If harbour porpoise populations in Southeast Alaska are organized in the same manner as those described for other study areas, this 
(a)
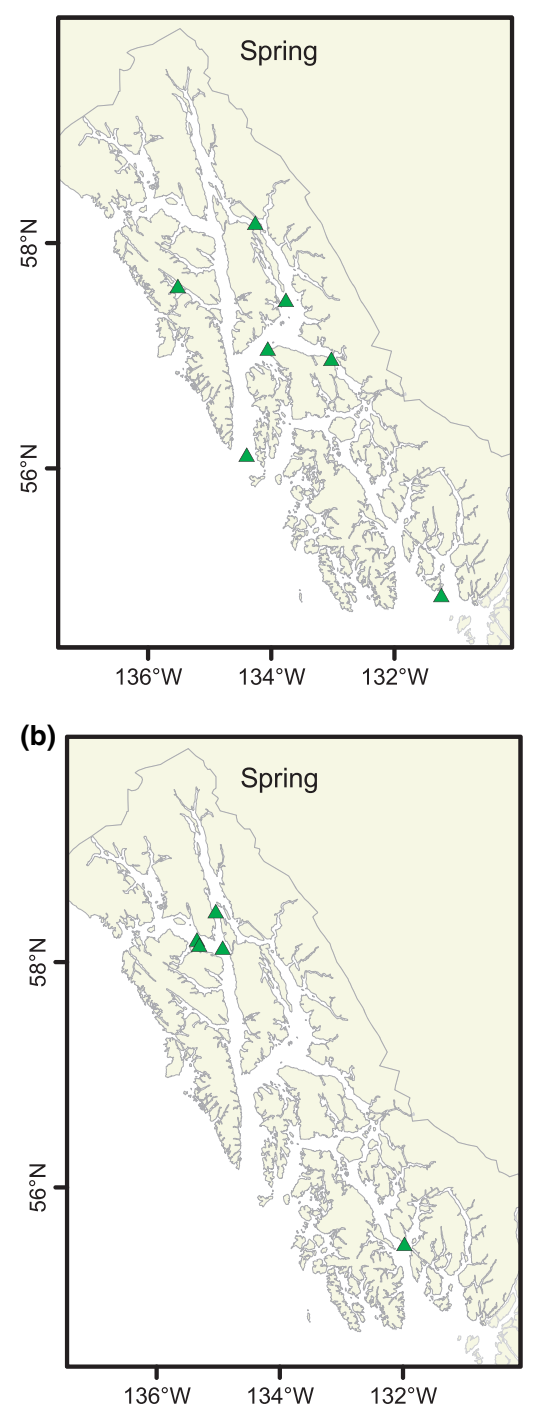

Transient killer whales
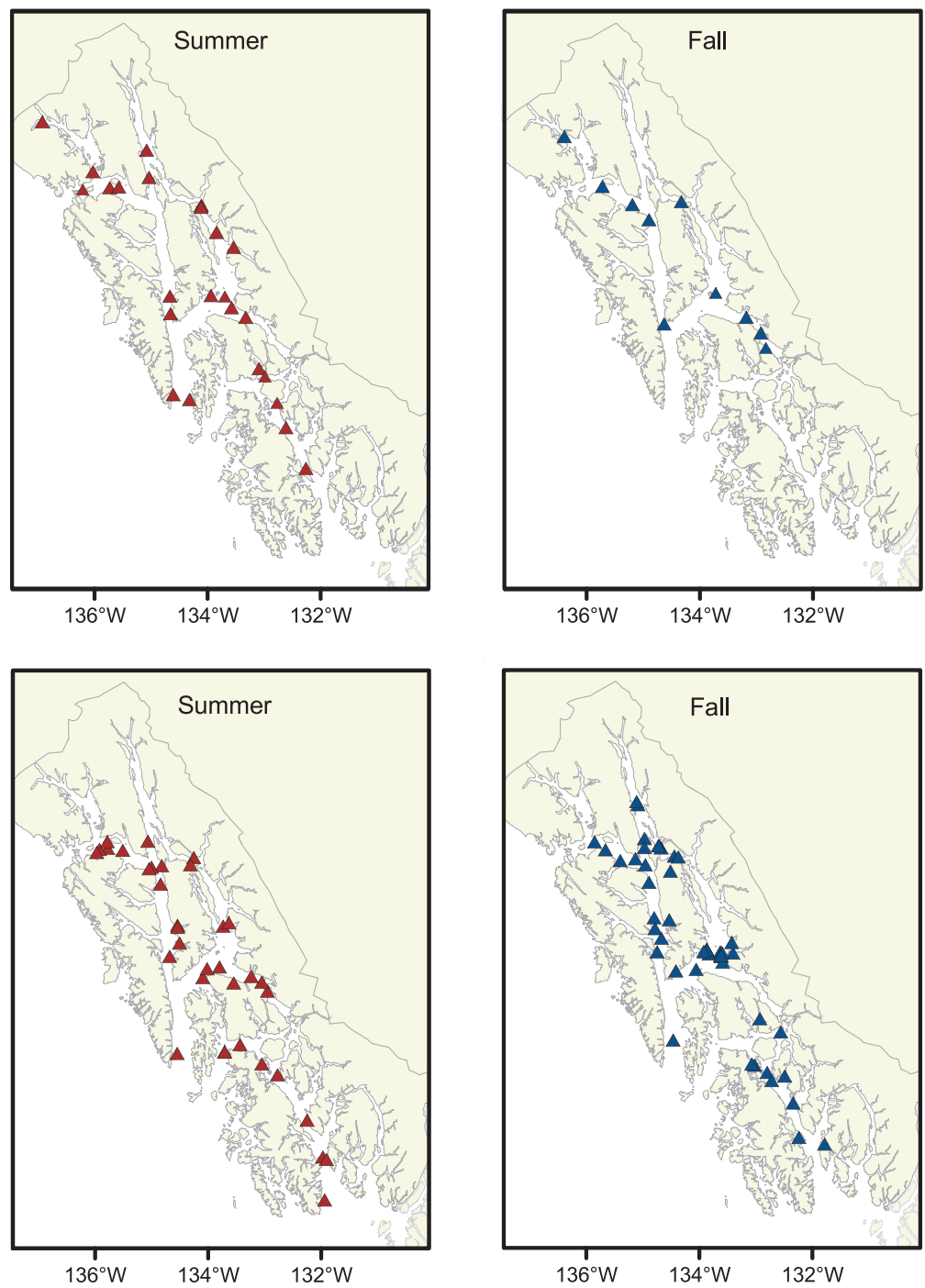

Figure 6 Seasonal distribution of transient killer whales (Orcinus orca) in Southeast Alaska. (a) 1991, 1992, 1993, 2006 and 2007, representing five line-transect cruises in spring, five cruises in summer and four cruises in fall; (b) 1994-2005, representing four non-linetransect cruises in spring, nine cruises in summer and eleven cruises in fall. Each dot indicates a group sighting/encounter.

would suggest minimal interchange between harbour porpoise populations in Glacier Bay and those in the Frederick Sound and Wrangell areas. Throughout the study, most sightings of Pacific white-sided dolphins were recorded in the southern portion of Southeast Alaska (i.e. Clarence Strait). However, in the spring season between 1992 and 1994 an exceptionally high number of Pacific white-sided dolphins were observed throughout Frederick Sound (central portion of study area; Dahlheim \& Towell, 1994). In a study of Pacific white-sided dolphins in northern British Columbia, Morton (2000) also encountered this species more frequently during this same time period (1992-94) than in any other year of her 15-year study (1984-98).

Concentrations of cetaceans are probably linked to the exploitation of highly localized resources that can change both spatially and temporally. Prey distribution is thought to be the major factor driving cetacean distribution (Krieger \& Wing, 1986). Southeast Alaska has long been considered as an important feeding area for humpback whales (Baker et al., 1986), and, when observed, humpback whales were typically engaged in overt feeding activities. Likewise, the presence of resident killer whales may be tied to the seasonal runs of Pacific salmon (Onchorynchus sp.) in Southeast Alaska. HeimlichBoran (1986) reported significant correlations between salmon occurrence and killer whales in Greater Puget Sound in Washington State. Similarly, the occurrence of transient killer whales at certain locales during particular seasons may be associated with the localized and seasonal availability of marine mammal prey (e.g. pinniped pups near rookeries or haul-outs; Small et al., 2003).

Less is known about the feeding habits of the other cetacean species that occur in this area. However, by comparing the 
(a)
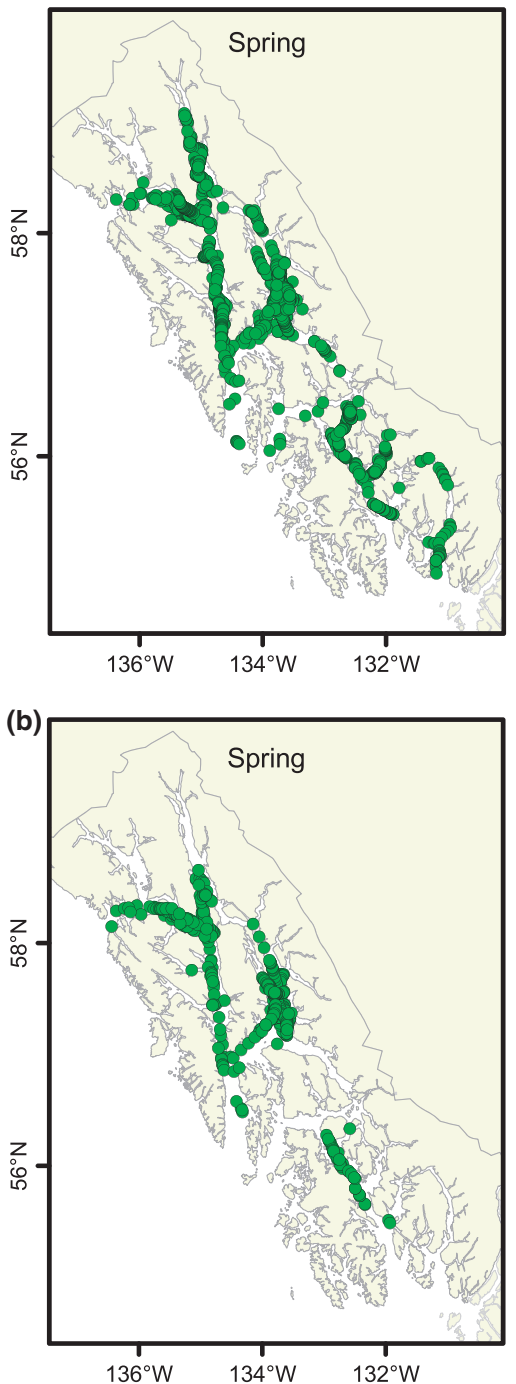

\section{Dall's porpoise}
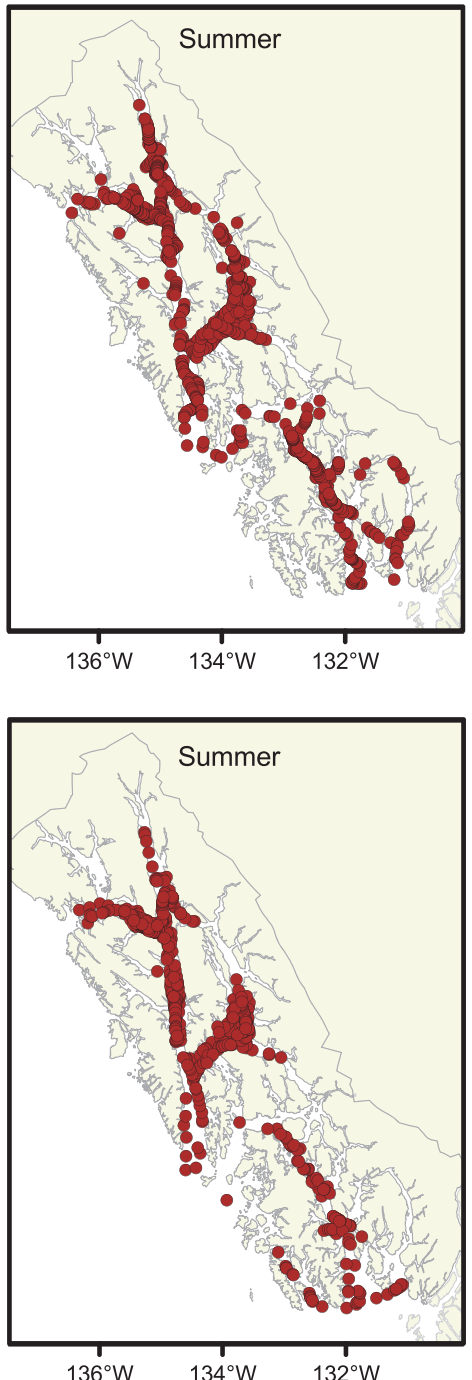

Fall
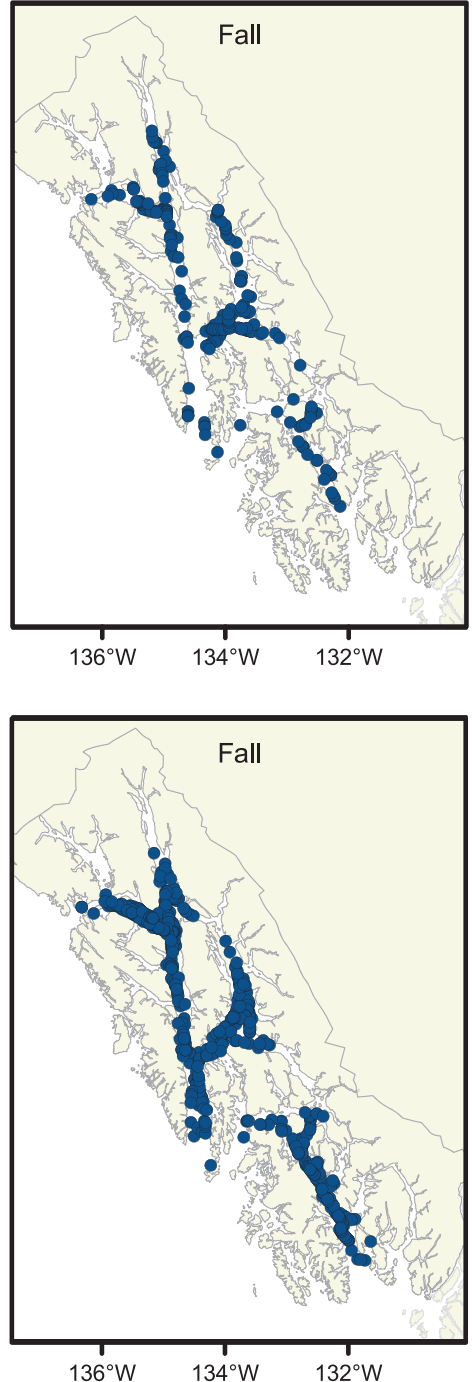

Figure 7 Seasonal distribution of Dall's porpoise (Phocoenoides dalli) in Southeast Alaska. (a) 1991, 1992, 1993, 2006 and 2007, representing five line-transect cruises in spring, five cruises in summer and four cruises in fall; (b) 1994-2005 representing four non-line-transect cruises in spring, nine cruises in summer and eleven cruises in fall. Each dot indicates a group sighting/encounter.

spatial and temporal patterns of cetaceans as found in this study with other oceanographic and biological features, it may be possible to make inferences about the types of prey being targetted. Of particular interest are the annually, re-occurring concentrations of cetaceans, especially in areas where several cetacean species congregate (e.g. Icy Strait and Frederick Sound). Also of interest are the species that exhibit little spatial overlap (e.g. harbour porpoise and Dall's porpoise), which appear to show more habitat specificity, possibly relating to dietary preferences. A more in-depth study of microhabitat use that investigates habitat partitioning (distance to shore, foraging depth, prey species targetted) among sympatric species is warranted to better understand the ecological relationships among cetacean species occupying this region.

Seasonal occurrence varied by species, but seasonal patterns for each species were found to be consistent each year. It was not surprising to find the seasonal pattern for humpback whales in Southeast Alaska, given that this species undertakes extensive annual migrations from warm-water, southern breeding grounds to the food-rich environments of colder, northern waters (Baker et al., 1986). We would also assume that fin whales and minke whales would move in and out of the waters of Southeast Alaska on a seasonal basis. In the case of killer whales, movements by each eco-type occur within a home range, and thus there are times when these animals are present and times when they are absent in the study area. For resident and transient killer whales we assume that their occurrence in the area is strongly linked to the presence and timing of their major prey items (i.e. salmon and marine mammals, respectively). Offshore killer whale occurrence in the area was sporadic, with few encounters occurring during the course of our study. Recently, Dahlheim et al. (2008) 
(a)
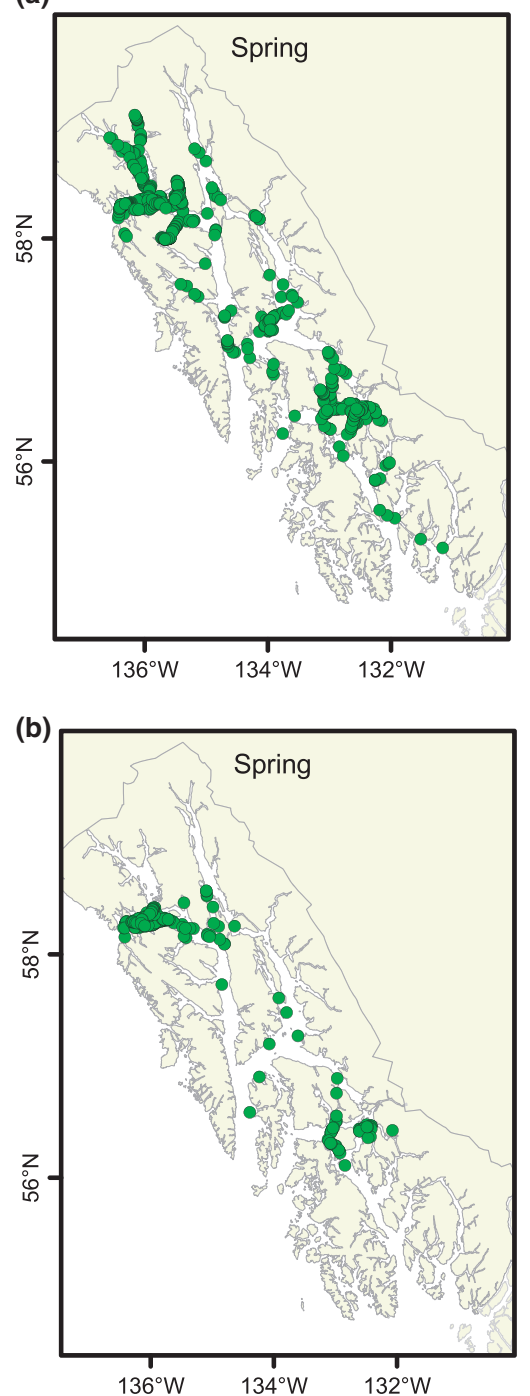

Harbour porpoise
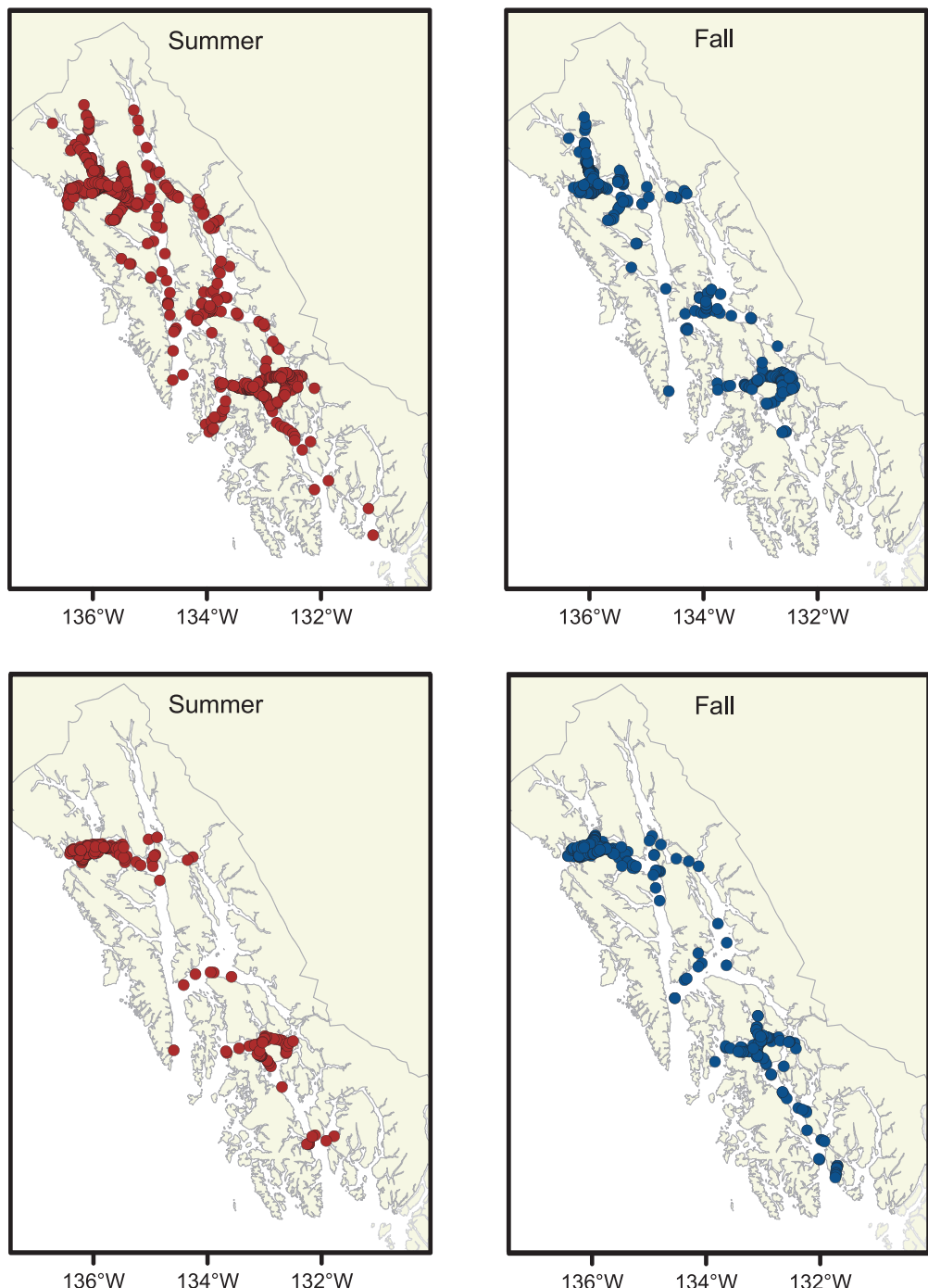

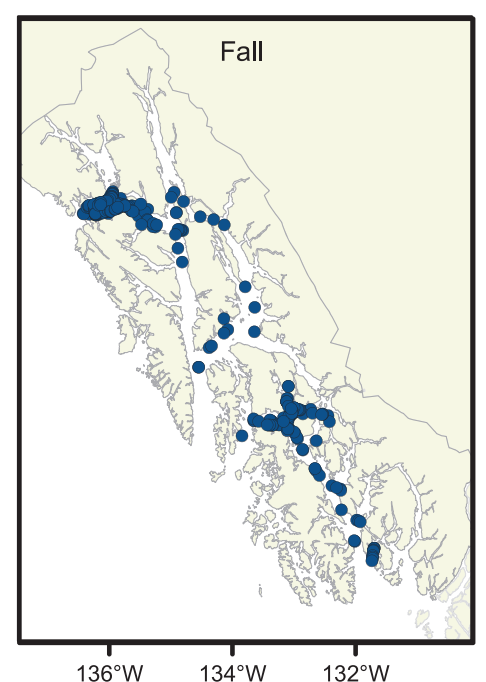

Figure 8 Seasonal distribution of harbour porpoise (Phocoena phocoena) in Southeast Alaska. (a) 1991, 1992, 1993, 2006 and 2007, representing five line-transect cruises in spring, five cruises in summer and four cruises in fall; (b) 1994-2005 representing four non-linetransect cruises in spring, nine cruises in summer and eleven cruises in fall. Each dot indicates a group sighting/encounter.

documented many of the individual offshore killer whales seen in Southeast Alaska visiting Californian waters during winter periods, suggesting that the presence of this eco-type in Southeast Alaska waters is seasonal. No seasonal patterns were detected for harbour porpoise, and our preliminary analysis of annual trends yielded only a slight increase of $0.2 \%$ for this population. However, given the size of the standard error (Table 4), this information should be viewed with caution and treated as tentative. A rigorous analysis of abundance and trend data is planned to address the population status of this species. For both Dall's porpoise and Pacific white-sided dolphins sighting rates were highest in the spring, with encounters decreasing during summer and fall periods.

This study spans the annual oceanographic cycle from after the first plankton bloom to before the water column becomes uniform (typically in mid to late October; Weingartner et al.,
2008). Thus all of our surveys were conducted during the time of year when the water column was stratified. As a result, the patterns reported here may not accurately reflect the spatial and temporal activities of cetaceans during the winter and early spring seasons. At present, only very limited data are available on the winter or early spring presence or relative abundance of cetaceans in Southeast Alaska. Straley (1990) reported humpback whales wintering in the waters of Southeast Alaska with overall numbers greatly reduced as compared with other seasons. Sporadic sightings of resident and transient killer whales, Dall's porpoise and harbour porpoise have been reported in the region during winter and early spring (NMML, unpublished data). By contrast, no reports could be found on the winter occurrence of fin whales, minke whales and Pacific white-sided dolphins in Southeast Alaska. The reduced number of sighting reports during winter periods could reflect less 
(a)
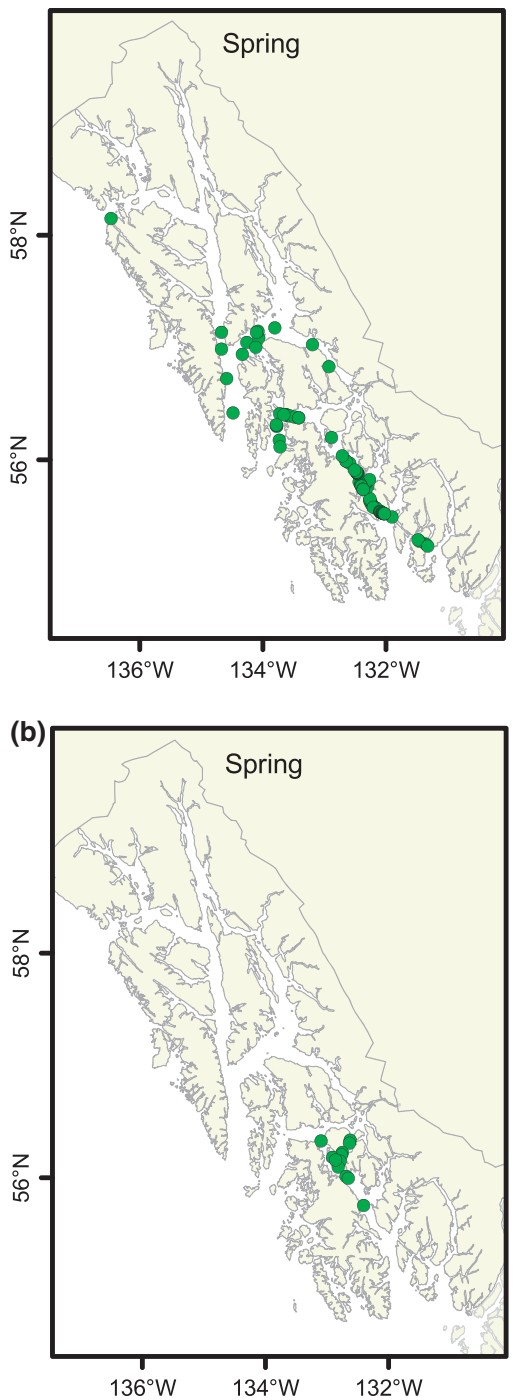

Pacific white-sided dolphins
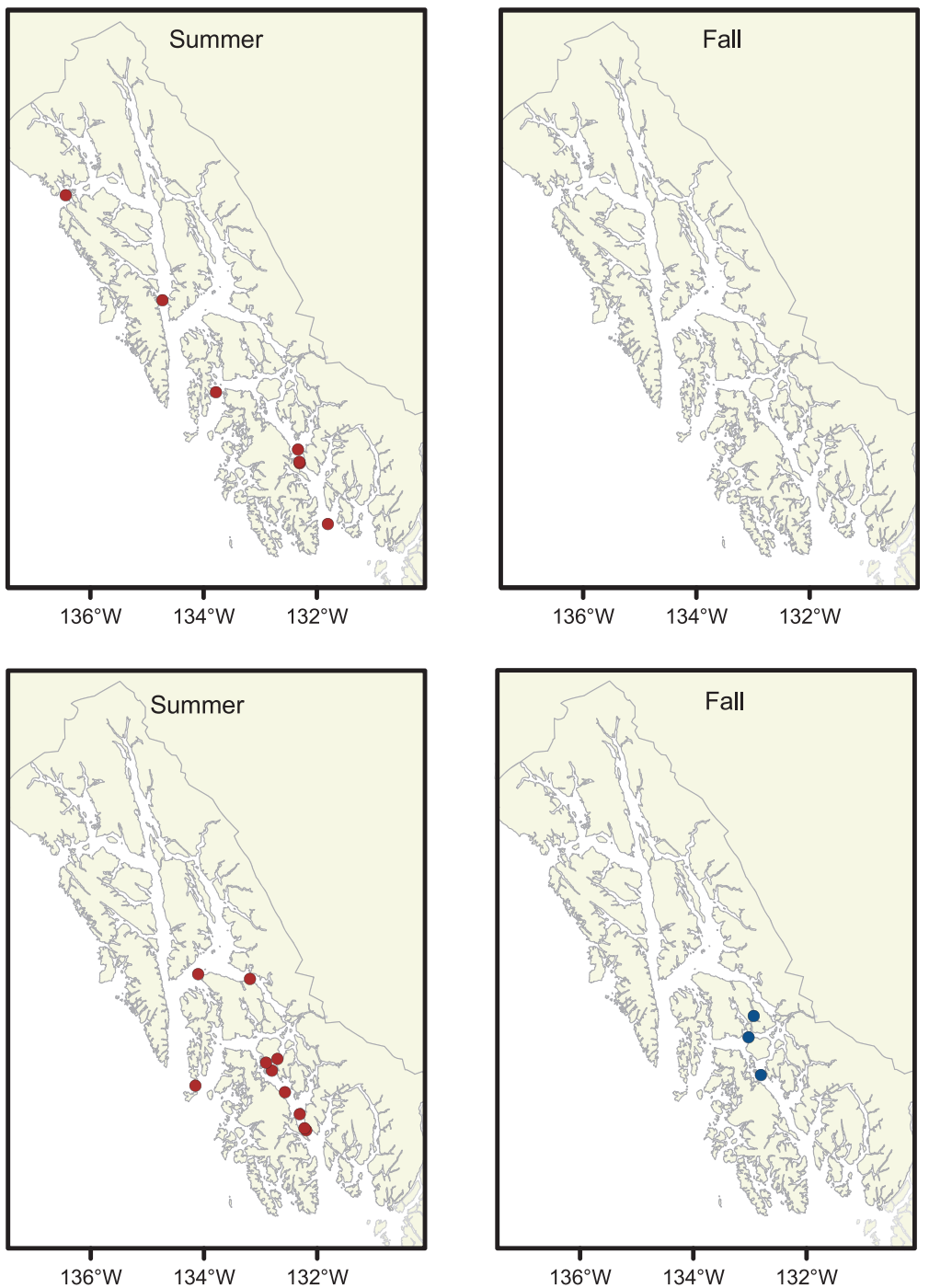

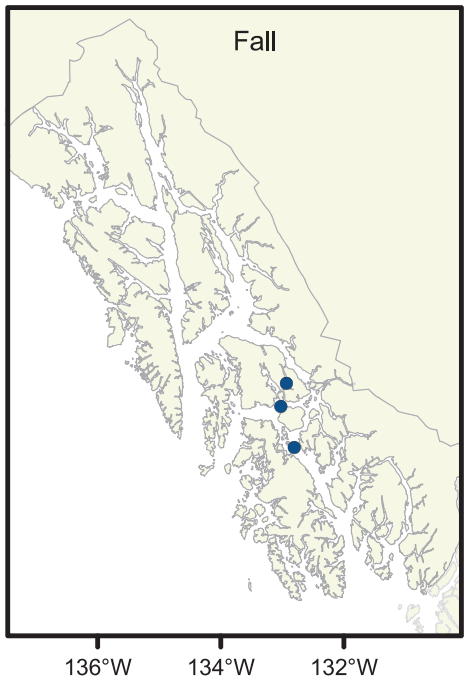

Figure 9 Seasonal distribution of Pacific white-sided dolphins (Lagenorhynchus obliquidens) in Southeast Alaska. (a) 1991, 1992, 1993, 2006 and 2007, representing five line-transect cruises in spring, five cruises in summer and four cruises in fall; (b) 1994-2005 representing four non-line-transect cruises in spring, nine cruises in summer and eleven cruises in fall. Each dot indicates a group sighting/encounter.

effort, fewer hours of daylight or inclement weather, or be a result of factors associated with the biology of the species (e.g. migratory behaviour).

Although there were some differences in methodology among the years, many of our methods did not vary. For example, the effect of the survey platform on our ability to sight cetaceans was negated given we had the same vessel for all survey work. In addition, many of the same observers or experienced observers participated in the different cruises, thereby reducing observer bias. We carefully considered the potential sources of sighting biases that could have arisen from the different methodologies employed as well as from the unequal effort that occurred during this study. Although all cetacean sightings were recorded during all surveys, the more intensive use of binoculars during line-transect years is likely to have resulted in a higher rate of detection of the less conspicuous porpoises. Furthermore, the line-transect surveys in 1991-93 had six observers, as opposed to the four observers during line-transect surveys conducted in 2006 and 2007 and during non-line-transect surveys (1994-2005). Having six observers allows for a longer rest period between watches, a factor that may have reduced observer fatigue and increased sighting reliability. These factors would have resulted in underrepresentation of the less conspicuous species during non-linetransect years. Despite these factors, a comparison of the two distributional maps produced for each species, depicting data collected on line-transect surveys and on non-line-transect surveys, shows similarities in overall seasonal distribution.

The marine ecosystem of Southeast Alaska is characterized by a wide spectrum of habitats. This area is well known 
for its deep-water fjords, tide-water glaciers, protected bays and inlets, abundant streams and rivers, shallow river deltas, and areas influenced by strong tidal currents. These factors combine to form a unique ecosystem that supports some of the most abundant marine life in the world (Ketchum \& Ketchum, 1994; Lindstrom, 2008; Straley et al., 2008; Weingartner et al., 2008; Womble et al., 2008). The richness and biodiversity of cetacean species found within this relatively small area is considered unique. Other regions such as the waters of the Arctic and Antarctic also attract an abundance of marine mammal species but over a considerably larger geographical scale. Cetacean occurrence was persistent over multiple years either on an annual or seasonal basis, thus demonstrating the importance and the reliance these species have on the inland waters of Southeast Alaska. Multi-year distributional data such as these not only enhance our understanding of cetacean ecology but can also be viewed as an indication of the overall health of the environment. Identifying the key factors that support the high density and biodiversity of cetaceans seen in the region is the next step to understanding the inter-specific ecology and long-term patterns of cetacean distribution and occurrence in Southeast Alaska. Future studies that compare the spatial and temporal patterns reported here with the oceanographic and biological features of the region will also help us to understand the ecological role that cetaceans may have on shaping marine ecosystems in other regions and greatly increase our ability to design and promote management strategies that ensure the long-term conservation of marine life on a global scale.

\section{ACKNOWLEDGEMENTS}

We express our deepest gratitude to all the captains and crews that served aboard the NOAA ship John N. Cobb. Their hard work and dedication to our cetacean research is greatly appreciated. Over the 17-year period, we have had numerous researchers participate in our cruises and we thank them all for many hours of work. Our thanks are also extended to Alex Zerbini and Jeff Laake, who assisted us with analyses of cetacean seasonal patterns and annual trends. Kim Shelden and John Durban reviewed this manuscript prior to journal submission. Thanks are extended to Wendy Carlson for assisting with Fig. 1. Gary Duker and James Lee provided editorial assistance with this manuscript.

\section{REFERENCES}

Baird, R.W. (2000) The killer whale - foraging specializations and group hunting. Cetacean societies: field studies on dolphins and whales (ed. by J. Mann, R.C. Connor, P.L. Tyack and H. Whitehead), pp. 127-153. University of Chicago Press, Chicago, IL.

Baird, R.W. \& Stacey, P.J. (1988) Variation in saddle patch pigmentation in populations of killer whales (Orcinus orca) from British Columbia, Alaska, and Washington State. Canadian Journal of Zoology, 66, 2582-2585.

Baker, C.S., Herman, L.M., Perry, A., Lawton, W.S., Straley, J.M. \& Straley, J.H. (1985) Population characteristics and migration of summer and late-season humpback whales (Megaptera novaeangliae) in southeastern Alaska. Marine Mammal Science, 1, 304-323.

Baker, C.S., Herman, L.M., Perry, A., Lawton, W.S., Straley, J.M., Wolman, A.A., Kaufman, G.D., Winn, H.E., Hall, J., Reinke, J.M. \& Ostman, J. (1986) Migratory movement and population structure of humpback whales (Megaptera novaeangliae) in the central and eastern North Pacific. Marine Ecology Progress Series, 31, 105-119.

Baker, C.S., Perry, A. \& Straley, J.M. (1992) Population characteristics of individually identified humpback whales in southeastern Alaska: summer and fall 1986. Fishery Bulletin, U.S., 90, 429-437.

Barlow, J. (1988) Harbor porpoise, Phocoena phocoena, abundance estimation for California, Oregon, and Washington: I. Ship surveys. Fishery Bulletin, U.S., 86, 417-432.

Bigg, M.A., Ellis, G.M., Ford, J.K.B. \& Balcomb, K.C. (1987) Killer whales: a study of their identification, genealogy, and natural history in British Columbia and Washington State. Phantom Press, Nanaimo, BC.

Braham, H.W. \& Dahlheim, M.E. (1982) Killer whales in Alaska documented in the Platforms of Opportunity Program. Report of the International Whaling Commission, 32, 643-646.

Chivers, S.J., Dizon, A.E., Gearin, P. \& Robertson, M. (2002) Small-scale population structure of eastern North Pacific harbor porpoise, Phocoena phocoena, indicated by molecular genetic analysis. Journal of Cetacean Research and Management, 4, 111-122.

Dahlheim, M.E. \& Towell, R.G. (1994) Occurrence and distribution of Pacific white-sided dolphins (Lagenorhynchus obliquidens) in Southeastern Alaska, with notes on an attack by killer whales (Orcinus orca). Marine Mammal Science, 10, 458-464.

Dahlheim, M.E., Ellifrit, D.K. \& Swenson, J.D. (1997) Killer whales of Southeast Alaska: a catalogue of photo-identified individuals. Day Moon Press, Seattle, Washington.

Dahlheim, M.E., York, A., Towell, R., Waite, J. \& Brewick, J. (2000) Harbor porpoise (Phocoena phocoena) abundance in Alaska: Bristol Bay to Southeast Alaska, 1991-1993. Marine Mammal Science, 16, 28-45.

Dahlheim, M.E., Schulman-Janiger, A., Black, N., Ternullo, R., Ellifrit, D. \& Balcomb, K.C. (2008) Eastern temperature North Pacific offshore killer whales (Orcinus orca): occurrence, movements, and insights in feeding ecology. Marine Mammal Science, 24, 719-729.

Dorsey, E.M. (1983) Exclusive adjoining ranges in individually identified minke whales (Balaenoptera acutorostrata) in Washington State. Canadian Journal of Zoology, 61, 174-181.

Dorsey, E.M., Stern, J.S., Hoelzel, A.R. \& Jacobsen, J. (1990) Minke whales (Balaenoptera acutorostrata) from the West Coast of North America: individual recognition and smallscale site fidelity. Individual recognition of Cetacea: use of 
photoidentification and other techniques to estimate population parameters (ed. by P.S. Hammond, S.A. Mizroch and G.P. Donovan), pp. 357-368. Report of the International Whaling Commission. Special Issue 12. International Whaling Commission, Cambridge, UK.

Ford, J.K.B., Ellis, G.M. \& Balcomb, K.C. (1994) Killer whales: the natural history and genealogy of Orcinus orca in British Columbia and Washington. University of Washington Press, Seattle.

Ford, J.K.B., Ellis, G.M., Barrett-Lennard, L.G., Morton, A.B., Palm, R.S. \& Balcomb, K.C. (1998) Dietary specialization in two sympatric populations of killer whales (Orcinus orca) in coastal British Columbia and adjacent waters. Canadian Journal of Zoology, 76, 1456-1471.

Gaskin, D.E. (1984) The harbour porpoise (Phocoena phocoe$n a)$ : regional populations, status, and information on direct and indirect catches. Report of the International Whaling Commission, 34, 569-586.

Heimlich-Boran, J.R. (1986) Fishery correlations with the occurrence of killer whales in Greater Puget Sound. Behavioral biology of killer whales (ed. by B.C. Kirkevold and J.S. Lockard), pp. 113-131. A. R. Liss, New York.

Hoelzel, A.R. \& Dover, G.A. (1991) Genetic differentiation between sympatric killer whale populations. Heredity, 66, 191-195.

Hoelzel, A.R., Dahlheim, M.E. \& Stern, S.J. (1998) Low genetic variation among killer whales (Orcinus orca) in the eastern North Pacific, and genetic differentiation between foraging specialists. Journal of Heredity, 89, 121-128.

Hoelzel, A.R., Natoli, A., Dahlheim, M.E., Olavarria, C., Baird, R.W. \& Black, N.A. (2002) Low worldwide genetic diversity in the killer whale (Orcinus orca): implications for demographic history. Proceedings of the Royal Society B: Biological Sciences, 269, 1467-1473.

Ketchum, R.B. \& Ketchum, C.D. (1994) The Tongass: Alaska's vanishing rain forest. Aperture Foundation, Inc., New York.

Krieger, K. \& Wing, B. (1986) Hydroacoustic monitoring of prey to determine humpback whale movements. National Oceanic and Atmospheric Administration Technical Memorandum. NMFS F/NWG-98. U.S. Dept. of Commerce, Seattle.

Laake, J.L., Buckland, S.T., Anderson, D.R. \& Burnham, K.P. (1993) DISTANCE user's guide, V.2.O. Colorado Cooperative Fish and Wildlife Research Unit, Colorado State University, Fort Collins, CO.

Leatherwood, S., Reeves, R.R., Perrin, W.F. \& Evans, W.E. (1982) Whales, dolphins and porpoises of the eastern North Pacific and adjacent Arctic waters. National Oceanic and Atmospheric Administration Technical Report, National Marine Fisheries Service Circular, 444, 1-245.
Lindstrom, S.C. (2008) The biogeography of seaweeds in Southeast Alaska. Journal of Biogeography, doi: 10.1111/ j.1365-2699.2007.01855.x.

Morton, A.B. (2000) Occurrence, photo-identification and prey of Pacific white-sided dolphins (Lagenorhynchus obliquidens) in the Broughton Archipelago, Canada 19841998. Marine Mammal Science, 16, 80-93.

$\mathrm{R}$ Development Core Team (2005) R: a language and environment for statistical computing. $\mathrm{R}$ Foundation for Statistical Computing, Vienna.

Scheffer, V.B. (1949) The Dall porpoise, Phocoenoides dalli, in Alaska. Journal of Mammalogy, 30, 116-121.

Scheffer, V.B. (1950) The striped dolphin, Lagenorhynchus obliquidens Gill 1865, on the coast of North America. American Midland Naturalist, 44, 750-758.

Small, R.J., Pendleton, G.W. \& Pitcher, K.W. (2003) Trends in abundance of Alaska harbor seals, 1983-2001. Marine Mammal Science, 19, 344-362.

Stevens, T.A., Duffield, D., Asper, E., Hewlett, K., Bolz, A., Gage, L. \& Bossart, G. (1989) Preliminary findings of restriction fragment differences in mitochondrial DNA among killer whales (Orcinus orca). Canadian Journal of Zoology, 67, 2592-2595.

Straley, J.M. (1990) Fall and winter occurrence of humpback whales (Megaptera novaengliae) in southeastern Alaska. Individual recognition of Cetacea: use of photoidentification and other techniques to estimate population parameters (ed. by P.S. Hammond, S.A. Mizroch and G.P. Donovan), pp. 319-323. Report of the International Whaling Commission. Special Issue 12. International Whaling Commission, Cambridge, UK.

Straley, J.M., Quinn, T.J., II \& Gabriele, C.M. (2008) Assessment of mark-recapture models to estimate the abundance of a humpback whale feeding aggregation in Southeast Alaska. Journal of Biogeography, doi: 10.1111/j.13652699.2008.01906.x.

Taylor, B.L. \& Dawson, P.K. (1984) Seasonal changes in density and behavior of harbor porpoise (Phocoena phocoena) affecting census methodology in Glacier Bay National Park, Alaska. Report of the International Whaling Commission, 34, 479-483.

Weingartner, T., Eisner, L., Eckert, G.L. \& Danielson, S. (2008) Southeast Alaska: oceanographic habitats and linkages. Journal of Biogeography, doi: 10.1111/j.1365-2699.2008. 01994.x.

Womble, J.N., Sigler, M.F. \& Willson, M.F. (2008) Linking seasonal distribution patterns with prey availability in a central-place forager, the Steller sea lion. Journal of Biogeography, doi: 10.1111/j.1365-2699.2007.01873.x. 
M. E. Dahlheim et al.

BIOSKETCHES

Marilyn E. Dahlheim has a PhD in zoology from the University of British Columbia. Since 1978, she has worked as a wildlife biologist at the Alaska Fisheries Science Center, National Marine Mammal Laboratory (NMML), in Seattle, Washington. Marilyn conducts marine mammal research throughout Alaskan waters with an emphasis on Southeast Alaskan cetacean biology and ecology.

Paula A. White has a PhD from the University of California Berkeley. She is currently a research associate with the University of California, Los Angeles. Paula specializes in the biology, ecology and social evolution of mammalian carnivores.

Janice M. Waite has a Master's degree in marine science from the University of California at Santa Cruz. She has been a biologist at the Alaska Fisheries Science Center, National Marine Mammal Laboratory in Seattle, Washington since 1991. Janice has been working primarily on the abundance and distribution of cetacean species in Alaska.

Editor: Ginny Eckert

The papers in this Special Issue arose from a workshop on Southeast Alaska marine biology and oceanography that was funded by the North Pacific Research Board and held March 30-31, 2005 at the University of Alaska Southeast in Juneau, Alaska, USA (http://doc.nprb.org/web/04_prjs/f0406_final_report.pdf). This is NPRB publication no. 191. 